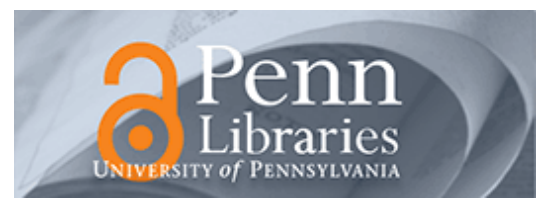

University of Pennsylvania

ScholarlyCommons

Management Papers

Wharton Faculty Research

$12-1-2016$

\title{
Funding Financial Inclusion: Institutional Logics and the Contextual Contingency of Funding for Microfinance Organizations
}

\author{
Adam Cobb \\ University of Pennsylvania \\ Tyler Wry \\ University of Pennsylvania \\ Eric Y. Zhao \\ Indiana University
}

Follow this and additional works at: https://repository.upenn.edu/mgmt_papers

Part of the Management Sciences and Quantitative Methods Commons

\section{Recommended Citation}

Cobb, A., Wry, T., \& Zhao, E. Y. (2016). Funding Financial Inclusion: Institutional Logics and the Contextual Contingency of Funding for Microfinance Organizations. Academy of Management Journal, 59 (6), 2103-2131. http://dx.doi.org/10.5465/amj.2015.0715

This paper is posted at ScholarlyCommons. https://repository.upenn.edu/mgmt_papers/184

For more information, please contact repository@pobox.upenn.edu. 


\title{
Funding Financial Inclusion: Institutional Logics and the Contextual Contingency of Funding for Microfinance Organizations
}

\author{
Abstract \\ Microfinance is a promising tool for addressing the grand challenge of global poverty. Yet, while many \\ studies have examined how microfinance loans affect poor borrowers, we know little about how \\ microfinance organizations (MFOs) themselves finance their lending activities. This is a significant \\ oversight because most MFOs do not self-fund their lending, but, rather, rely on loans from external \\ funders. To better understand microfinance funding, we apply and extend the institutional logics \\ perspective to analyze the lending practices of commercial and public funders, who together provide \\ most of the capital for global microfinance. We argue that these funders adhere to financial and \\ development logics, respectively, and that this leads them to invest in different types of MFOs. Yet, in the \\ face of uncertainty, we suggest that the practices motivated by these logics will start to converge in ways \\ that are problematic for a nation's microfinance sector. Using a proprietary database of all traceable loans \\ to MFOs from 2004 to 2012, we find strong support for our hypotheses. In particular, our findings show \\ that the relationship between institutional logics and organizational practices is contextually contingent, \\ and this insight contributes important understanding about the efficacy of microfinance as a poverty- \\ reduction tool.
}

\section{Keywords}

institutional logics, microfinance, poverty, social enterprise, uncertainty

\section{Disciplines}

Management Sciences and Quantitative Methods 


\title{
Funding Financial Inclusion: Institutional Logics and the Contextual Contingency of Funding for Microfinance Organizations
}

\author{
J. Adam Cobb* \\ Assistant Professor of Management \\ The Wharton School \\ University of Pennsylvania \\ Tyler Wry \\ Assistant Professor of Management \\ The Wharton School \\ University of Pennsylvania \\ Eric Yanfei Zhao \\ Assistant Professor of Management and Entrepreneurship \\ The Kelley School of Business \\ Indiana University
}

Acknowledgements: The authors gratefully acknowledge the excellent suggestions and support provided by Laszlo Tihanyi and the three anonymous reviewers. We also thank Matthew Bidwell, Mauro Guillen, Martine Haas, Vit Henisz, Zeke Hernandez, Michael Lounsbury, Ethan Mollick, and seminar participants at Boston College, Harvard Business School, Indiana University DRSS, the University of Michigan, the National University of Singapore, and the 2015 Community for Social Impact Conference for thoughtful comments on earlier versions of the paper. Financial support was provided by the Wharton Social Impact Initiative.

*Authors contributed equally and are listed in alphabetical order 


\title{
Funding Financial Inclusion: Institutional Logics and the Contextual Contingency of Funding for Microfinance Organizations
}

\begin{abstract}
Microfinance is a promising tool for addressing the grand challenge of global poverty. Yet, while many studies have examined how microfinance loans affect poor borrowers, we know little about how microfinance organizations (MFOs) themselves finance their lending activities. This is an important oversight because most MFOs do not self-fund their lending, but rather rely on loans from external funders. To better understand microfinance funding, we apply and extend the institutional logics perspective to analyze the lending practices of commercial and public funders, who together provide most of the capital for global microfinance. We argue that these funders adhere to financial and development logics, respectively, and this leads them to invest in different types of MFOs. Yet, in the face of uncertainty, we suggest that the practices motivated by these logics will start to converge in ways that are problematic for a nation's microfinance sector. Using a proprietary database of all traceable loans to MFOs from 2004 to 2012, we find strong support for our hypotheses. Our findings show that the relationship between institutional logics and organizational practices is contextually contingent, and that this insight contributes important understanding about the efficacy of microfinance as a poverty-reduction tool.

(196 words)
\end{abstract}


Over the past several decades, microfinance has emerged as a globally popular tool to reduce poverty. By providing small loans, microfinance organizations (MFOs) help to alleviate financial constraints for the poor and support consumption choices that increase household welfare and/or provide avenues for future ongoing income (Yunus, 1999). Today, MFOs operate in almost every nation of the world and collectively account for an estimated US\$60-100 billion in yearly loans (Lahaye, Rizvanolli, \& Dashi, 2012; Luminis, 2012).

The ability for microfinance to effectively combat poverty depends, in large part, on its ability to reach markets where individuals who need capital can obtain it. At its most basic, there are three key actors in the microfinance industry: borrowers, who apply for and receive loans; MFOs, which issue loans to borrowers; and funders, which supply capital to MFOs. To date, most research has focused on the first two. While this has generated useful insight about how MFOs operate and the effects they have on poor borrowers, we know little about how MFOs fund their operations. This is an important oversight, as most MFOs are unable to mobilize deposits to finance their lending and thus require external funds to meet their financial and social objectives. As such, access to funding is a critical factor in determining the overall health of the microfinance industry, as well as its efficacy as a poverty-reduction tool.

Research on capital acquisition by profit-seeking firms has found that investors are attracted to organizations that pose low investment risk and have the potential to generate strong returns (e.g., Katila, Rosenberger, \& Eisenhardt, 2008). Yet in microfinance it is important that there are also funders who support sectoral development and social outreach. Reflecting this, practitioner research has argued that the health and impact of a nation's microfinance sector rely on contributions from two main types of funders: commercial funders, which raise private capital to invest in MFOs; and public funders, which channel governmental funds to MFOs (Reille, Forster, \& Rozas, 2011). Researchers have assumed these funders have different interests and lending practices, but this has not been subjected to rigorous empirical analysis. Academic 
studies have mostly examined factors that affect the price of funding in a nation (Garmaise \& Natividad, 2013; Tchuigoua, 2014). Practitioner studies have differentiated among funders but offer conflicting accounts about their lending practices (Gonzalez, 2010; Von Stauffenberg \& Rosas, 2011). Hence, despite expected differences in their objectives, we know little about the actual lending behavior of different funder types, how their behavior might vary across contexts, or the effect their behavior has on a nation's microfinance sector.

To help address these questions, we develop a theoretical approach that applies and extends insights about institutional logics, which are sets of shared beliefs that rationalize the value of particular goals and interests (Thornton, Ocasio, \& Lounsbury, 2012). In recent years, logics have become a popular tool for explaining organizational action. This work argues that logics shape action because they are embedded in the cognition of an organization's decisionmakers, providing them with a framework that guides attention and helps to discern appropriate behavior in a given context (Almandoz Rios, 2014). Thus, within the same field or industry, stable differences are often observed in the practices of organizations that adhere to different logics (e.g., Pahnke, Katila, \& Eisenhardt, 2015). We apply this framework to microfinance funding to generate baseline predictions about the lending behavior of different types of funders.

Still, we argue that stopping here would provide a partial account, as it overlooks the possibility that the link between logics and practices is contextually contingent. While most accept that logics can support a variety of practices, studies to date have focused on idiosyncratic behavioral shifts that result from learning, random drift, or strategic deviation within a given context (Clemens \& Cook, 1999; Lounsbury \& Crumley, 2007). Yet we know that firms often operate in multiple environments (Vasudeva, Zaheer, \& Hernandez, 2013) and that practices can shift in response to local contingencies (Boxenbaum \& Battilana, 2005). Extending this, we suggest that firms that adhere to a particular logic may behave in systematically different ways in different contexts. To this end, our argument connects the logics perspective with research on 
how organizations respond to uncertainty in their external environment. Uncertainty disrupts the link between an organization's actions and expected outcomes, creating an impetus for strategic change (Audia, Locke, \& Smith, 2000; Davis, Eisenhardt, \& Bingham, 2009). We suggest that because logics shape how decision-makers perceive and respond to the environment, attention will shift in response to uncertainty leading to behavioral changes that are guided by a firm's orienting logic. In short, the practices seen as appropriate for pursuing a given set of interests may differ in placid versus uncertain contexts. This is germane to our study, as microfinance funders-like many organizations that work to address social challenges-operate in nations where there are varying levels of political and economic uncertainty (Marquis \& Raynard, 2015).

To apply our theory, we first distinguish between commercial and public funders as the main capital providers in global microfinance. Based on the practitioner literature, as well as interviews with over 30 industry informants, we discern the logics that these funders adhere to and use this to make predictions about their lending behavior. We argue that commercial funders adhere to a financial logic that emphasizes investment return and supports a focus on large, financially strong MFOs. By comparison, public funders adhere to a development logic that prioritizes the health and efficacy of a nation's microfinance sector and thus favors small, notyet-sustainable MFOs that do not appeal to commercial funders (Griffith \& Evans, 2012).

As a nation becomes more uncertain, we predict that commercial funders will place more emphasis on MFO size and less on financial performance: large MFOs are likely to be viewed as stable and thus more likely to provide the funder with its desired financial return. However, past performance has less predictive power in such contexts, making it a less-reliable investment risk indicator (Davis et al., 2009). We also predict MFO size will become important to public funders as uncertainty rises. These funders rely on capital recovery to sustain their development efforts; if an MFO defaults on its loans, funders have less money to invest in subsequent projects (Griffith \& Evans, 2012). Moreover, if an MFO becomes insolvent, it does not contribute to a 
healthy microfinance sector. Thus, from the funder's perspective, lending to large MFOs is a pragmatic way to support sector development under uncertainty. We thus expect the lending practices of commercial and public funders to converge as uncertainty rises, even as the two are guided by different logics. Given that the need for microfinance rises when a nation becomes volatile and that sector growth and outreach are constrained when funding clusters in large MFOs (Von Stauffenberg \& Rosas, 2011; Wiesner \& Quien, 2010), our arguments expose a challenge for global microfinance with potential implications for millions of poor borrowers.

We test our arguments using a proprietary database of all traceable loans made between funders and MFOs from 2004 to 2012. We model the amount and type of funding received by each MFO each year and use country-fixed effects to isolate the effect of changing uncertainty. Our results, along with numerous robustness checks and supplementary analyses, provide strong support for our predictions. Our approach contributes understanding about the link between institutional logics and organizational practices by showing that, while logics shape action, the

outcomes this yields may differ in systematic ways as the environment changes. By applying this argument, we also show the contextual nature of microfinance funding and generate a number of practical insights that may help increase the efficacy of microfinance as a poverty-reduction tool.

\section{THEORY AND HYPOTHESES}

\section{Microfinance Funding and Poverty Reduction}

Banks face high transaction costs when making and monitoring small loans; as a result, the poor are generally excluded from the formal financial system. This increases exposure to financial uncertainty, makes it difficult to start businesses, and forces the poor to rely on exploitative local lenders - all of which contribute to enduring poverty (Ledgerwood, Earne, \& Nelson, 2013). Originally, microfinance worked to address the exclusion problem by providing small loans designed to help the poor start and grow micro-enterprises. The rationale was that operating revenue from these businesses could be used to repay the loan, while also creating an 
ongoing source of sustainable income. The sector has since developed a less-restrictive lending focus and now provides a more expanded set of services to the poor (Ledgerwood et al., 2013).

Not surprisingly, there has been considerable scholarly attention examining the impacts of microfinance, with a number of studies highlighting its positive effects. There is evidence that loans help the poor to absorb unforeseen expenses and foster a long-term orientation in their consumption decisions (Karlan \& Zinman, 2010). Per the sector's original focus, studies have also shown that microfinance supports the creation and growth of small businesses. While there is variance in the success of these ventures, the net effect is typically a contribution to household income (Banerjee, Duflo, Glennerster, \& Kinnan, 2015). Microfinance also delivers benefits by focusing on women borrowers. On average, women dedicate a larger portion of loan proceeds to health and education expenses, both of which contribute to poverty reduction (Angelucci, Karlan, \& Zinman, 2012). For unmarried women, loans also provide an avenue for economic participation outside of the informal or illegal economy (Mair, Marti, \& Ventresca, 2012). ${ }^{1}$

While it is important to understand how microfinance affects borrowers, the question of how MFOs finance their lending activities has been largely overlooked. This omission is important because, whereas banks finance their lending through deposits, most MFOs cannot accept deposits and thus depend on external funders for the capital required to make loans and grow their operations (Morduch, 2000). In total, MFOs receive about US\$30 billion per year in funding, mostly from interest-bearing loans. ${ }^{2}$ Although the relative breakdown varies by region, it is estimated that about 80 percent of this funding reaches poor borrowers (Lahaye et al., 2012). Thus, for most MFOs, lending capacity is a direct function of external capital received.

In addition to organization-level implications, the overall health and impact of a nation's microfinance sector are determined, in part, by how funds are allocated among MFOs. It is

\footnotetext{
${ }^{1}$ Importantly, there are several studies highlighting concerns and challenges associated with microfinance. For example, see Battilana \& Dorado (2010), Karim (2011), Polgreen \& Bajaj (2010), and Viada \& Gaul (2012).

${ }^{2}$ Estimates suggest that the overall value of debt financing in microfinance outpaces other instruments, such as grants and equity, by a ratio of about five to one (Lahaye, Rizvanolli, \& Dashi, 2012).
} 
important that each nation's sector comprises many well-functioning and socially committed MFOs, as this leads to greater loan volumes, higher overall outreach levels, and competition that promotes better service and lower interest rates (e.g., Lützenkirchen, Weistroffer, \& Speyer, 2012). For this to happen, though, funding needs to be available not just to large, financially sustainable MFOs but also to those that are small, highly committed to social outreach, not yet self-sustaining, and more likely to default on their loans (Reille et al., 2011; Wiesner \& Quien, 2010). Accomplishing this goal therefore necessitates the existence of funders that are willing to accept more risk in their investments in order to meet these development objectives.

To date, however, there has been little research examining the lending practices of different types of microfinance funders. A handful of academic studies have examined the overall price of financing in a country, irrespective of lender differences. This work has found that MFOs pay less interest when their nation has strong market-supporting institutions (Tchuigoua, 2014) and when loans come from nations that are politically similar to their own (Garmaise \& Natividad, 2013). By comparison, practitioner research has differentiated between funders, identifying two main types: commercial and public. Yet this work casts doubt as to whether the two lend to different types of MFOs (Gonzalez, 2010; Von Stauffenberg \& Rosas, 2011). Thus, while a strong microfinance sector requires that capital be available to support diverse MFOs, we have little insight into the practices of different funders or the conditions under which their behavior creates a healthy funding ecology in a nation. We argue that an approach based in institutional logics can help advance insight here, as it directs attention to the sources of rationality that underpin an organization's interests, and thus provides leverage for theorizing about the aims of different funders as well as the MFO attributes that they attend to and value when making investment decisions (Thornton et al., 2012).

\section{An Institutional Logics Approach to Microfinance Funding}

The institutional logics perspective focuses on explaining how organizational action is 
shaped by shared sets of beliefs - or cultural influences - that rationalize the value of particular interests and identities (Thornton et al., 2012). As with other neo-institutional approaches, studies have shown that logics create expectations for how an organization should appropriately act within a given context and work through a variety of external channels to promote aligned action (Wry, Cobb, \& Aldrich, 2013). A unique feature of the logics approach, though, is the recognition that logics are also internalized by organization members and thus affect how managers allocate their attention, interpret external stimuli, and make decisions (Thornton \& Ocasio, 1999). As scholars increasingly come to recognize that organizations face institutionally complex environments that comprise conflicting external demands, the link between logics and managerial cognition has taken on heightened importance for understanding organizational behavior (Battilana \& Dorado, 2010; Greenwood, Raynard, Kodeih, Micelotta, \& Lounsbury, 2011; Wry \& York, 2015; Zhao, Fisher, Lounsbury, \& Miller, 2016). In this regard, there is evidence that logics affect which external influences a firm attends and responds to (Pache \& Santos, 2013), while also guiding its action across diverse institutional contexts (Vasudeva et al., 2013). In short, scholars have posited a close and mutually constitutive link between logics and action, where a firm's internal operations and external practices are traced to "logic-consistent decisions that reinforce extant...identities and strategies" (Lounsbury, 2007: 289).

Notably for our purposes, there is also evidence that different types of organizations within a field or industry may adhere to different logics, and behave in consistently different ways as a result. Providing evidence of this, Rao and colleagues (2003) found that French restaurants differed with regard to cooking practices, ingredients, and dishes produced depending on whether they adhered to the logic of classical or nouvelle cuisine. Similar patterns have been found among investment firms. For example, Lounsbury (2007) found that the strategies of different mutual funds were anchored in either professional or trustee logic: the former used active money management practices, while the latter focused on long-term investing. There is 
also evidence that banks that operate according to community logic are more likely than national banks to lend to local businesses and prioritize local relationships (Almandoz Rios, 2014; Marquis \& Lounsbury, 2007). Pahnke and colleagues (2015) showed that venture capitalists, corporate investors, and government agencies each function according to a unique logic that leads to practices that variously enable or constrain innovation among fund recipients.

While these studies show that logics can shape investment practices, in each case funders are investing in commercial businesses with the aim of generating financial returns. Yet, in contexts like ours, where organizations seek financial and social returns (see also Battilana \& Lee, 2014), it is important to consider the varying, and nonpecuniary, motives that different funders might have. We thus build on existing work by drawing on the microfinance literature, as well as interviews with over 30 industry informants, to discern the logics that motivate different microfinance funders and use this to make predictions about their investment behavior. We began by interviewing funders with whom we had preexisting relationships, and asked each to introduce us to others that they knew. Next, we identified contacts for the remaining funders in our database and sent each an interview invitation. Overall, this yielded 34 interviews, conducted either online or by phone, 19 of which were with commercial funders. Table 1 summarizes each lender type, including information on subtypes and the scale of funding provided. As with previous studies, (e.g., Von Stauffenberg \& Rosas, 2011), our research focuses on commercial and public funders because they account for the large majority $(97 \%)$ of microfinance funding. ${ }^{3}$

-----Insert Table 1 about here-----

\section{Commercial Funders and Financial Logic}

Commercial funders are primarily investment funds and private equities that raise money from private investors to lend to MFOs; traditional banks that lend to MFOs are also included in this category. While there are local commercial funders in most nations, the majority-funds and

\footnotetext{
${ }^{3}$ We also analyzed lending practices for charitable funders (see https://mfifunding.wordpress.com).
} 
private equities in particular — are based in the United States or Western Europe (Sapundzhieva, 2011). After performing local due-diligence, most funding decisions are made by an investment committee at the funder's head office (Gonzalez, 2010). As a category, commercial funders are the largest and fastest-growing capital source in global microfinance (Lahaye et al., 2012).

Commercial funders' basis of interest. The interests of commercial funders are guided by a financial logic that prioritizes investment return. This is obvious for banks, which base their lending decisions on an analysis of borrower repayment capacity. Investment funds and private equities may also aspire to "do good" with their investments but, as with banks, lending decisions follow a financial calculus (Lützenkirchen et al., 2012). For most, social returns come simply from investing in microfinance, while others apply a set of screens to ensure money is not going to MFOs with usurious lending practices (Glisovic \& Moretto, 2012). In either case, once a consideration set of potential investment targets has been cultivated, the aim is to achieve market or near-market returns that generate revenue for the funder and entice people to invest in their products. For instance, BlueOrchard (2015), a microfinance investment fund, advertises that it helps "investors obtain strong financial returns while contributing to financial inclusion in emerging economies." Describing in more detail what this means from the funder perspective, many of our interviewees gave candid explanations for why financial returns are crucial. Per one fund manager, “[We're] like any other commercial lender; if we lose people's money or miss the return we're promising, there's no way we'll be able to raise another fund." Said another, "We need returns to capital and need to make sure we're involved with [MFOs] who can ensure this...it's a pure investment case driving our decisions." Covering the entire investment process, a private equity manager told us 'We start by applying screens...once we've got the initial consideration set put together, we need to [look] for the best bets."

Commercial funders' basis of action. Microfinance funders face the risk that an MFO (i.e., borrower) will not be able to fulfill the obligations of the loan agreement. Thus, given their 
interests, it is reasonable to expect that commercial funders will focus their attention on MFOs that pose the least risk of defaulting on their loans (Gonzalez, 2010). As in other investment contexts, there is evidence that size and financial performance are core indicators of an MFO's default risk (Berk, 1995; Fama \& French, 2012; Petersen \& Rajan, 1994). ${ }^{4}$

Size acts as a proxy for a number of hard-to-observe risk factors. Studies routinely find that large firms have less-volatile performance (Berk, 1995). Larger firms are also thought to be more legitimate (Greenwood \& Suddaby, 2006), of higher status (Haveman, 1993), and endowed with a greater amount of slack resources (George, 2005). Size is also a visible indicator that is easy to compare across organizations and gives evidence of past success and future stability (Geroski, Mata, \& Portugal, 2010). As such, it is commonly linked to organizational stability and performance (see Josefy, Kuban, Ireland, \& Hitt, 2015). In microfinance, large MFOs are also more likely to be integrated into a nation's banking sector, which helps to buffer against liquidity concerns (Cull, Demirguc-Kunt, \& Morduch, 2009; Reille \& Forster, 2008).

By comparison, financial performance is a direct indicator of a firm's solvency and a strong proxy of its ability to repay loans (Fama \& French, 2012). Studies suggest that performance is closely attended to by organizational decision-makers, who are generally more interested in partnering with and investing in firms that have strong versus weak performance (Li \& Rowley, 2002; Wry, Lounsbury, \& Jennings, 2014). Furthermore, and germane to our context, the influence of financial performance in such decisions appears to be particularly strong in emerging markets (Geringer, 1991; Hitt, Dacin, Levitas, Arregle, \& Borza, 2000).

Reflecting this, the practitioner literature suggests that microfinance funders rely heavily on size and financial performance to assess an MFO’s riskiness (Mersland \& Strom, 2010;

\footnotetext{
${ }^{4}$ Though it is common for individuals to use the terms "risk" and "uncertainty" interchangeably, some scholars have attempted to differentiate the two constructs. Following Knight (1921) — and consistent with the language used by the funders we spoke with - we treat risk as a condition in which an actor can assign probabilities to potential outcomes. In our context, the primary risk confronting funders is the probability that an MFO will be unable to pay back the loan and thus defaults. Conversely, uncertainty is a condition in which outcomes are unknowable and thus outcome probabilities cannot be assigned a priori (Knight, 1921; Sanders \& Hambrick, 2007). Based on this distinction, in our case uncertainty tends to exacerbate the investment risks faced by microfinance funders.
} 
MicroRate, 2013). ${ }^{5}$ As a fund manager told us, "We like big and stable MFOs...ones that are the key players in their market." Another fund manager remarked, "[I invest in] big MFOs [because they] are more likely to have experience, successful business models, and an established customer base." Each commercial funder we spoke to also reported looking closely at an MFO's financial position before investing. Stated plainly by a private equity manager, this meant that "for us to even look at you, you need to be clearly beating the market," while another reported that "we like [MFOs] with a good loan book and sound fundamentals because they're the most likely to get our money back to us." Based on these considerations, we predict the following:

Hypothesis 1. Within a country, the (a) size and (b) financial performance of an MFO is positively associated with the amount of loans it receives from commercial funders.

\section{Public Funders and Development Logic}

Public funders include government departments and aid agencies, as well as development finance institutions (DFIs). These funders are typically seeded with an endowment from one or more national governments, from which they offer subsidized loans to ventures deemed too risky for commercial investors (Griffith \& Evans, 2012). Public funders may be local or foreign and, as with commercial funders, investment decisions are typically centralized in the organization's head office (Gonzalez, 2010; Hoffman, 1998). These funders were among the first to invest in microfinance and remain a key capital source (Lafourcade, Isern, Mwangi, \& Brown, 2006).

Public funders' basis of interest. Public funders operate according to a development logic, where the primary aim is to support the health and social impact of a nation's microfinance sector (Von Stauffenberg \& Rosas, 2011). To this end, they are interested in fostering the growth and sustainability of target organizations, thus contributing to the emergence of more healthy MFOs in a nation and the increased competition and social outreach this brings (Otero \& Rhyne, 1994). Revenue from these loans is reinvested to support the funder's ongoing development

\footnotetext{
${ }^{5}$ Some research in microfinance has identified a third factor that can be used to assess MFO riskiness: transparency, which reflects the quality of an organization's financial reporting. Because we have no a priori expectation that funders will differ in their preference for MFO transparency, we only hypothesize relationships between size and financial performance on the one hand and funder type on the other. We control for transparency in our analyses.
} 
efforts (Griffith \& Evans, 2012). Hence, though loans are made on a cost-recovery basis, public funders are not financially motivated in the same way as commercial funders. Capturing this well, Goodman (2007: 21) notes that "[public funders] make capital available to [MFOs] through sustainable mechanisms to support their development and growth...typical financial targets [are] to maintain the original capital invested." This was echoed by our interviewees, such as one DFI officer who reported that, "The whole investment process is different than for commercial funders... [we look] to fund growth and capacity building." Offering further insight into the importance of these aims, another interviewee asserted, "We're a mission-driven organization and this means [we're] interested in developing the sector and...supporting poverty alleviation."

Public funders' basis of action. To pursue their development aims, public funders espouse a lending focus that targets MFOs that would not be deemed creditworthy by commercial lenders. Whereas commercial funders are likely to invest in large, financially strong MFOs, public funders focus their attention on supporting those that are small and not yet selfsustaining (Griffith \& Evans, 2012; Reille et al., 2011). The rationale is that lending to these MFOs can help them to expand operations and develop their internal capacities to the level where they are able to access commercial capital. Once this is accomplished, public funders move on and invest in the next round of emerging MFOs, furthering the development of a nation's microfinance sector (Otero \& Rhyne, 1994). As a government official told us, [Public funders] are the first ones into [an MFO]. We help to build capacity and are willing to take risks that others won't. By focusing on emerging [MFOs], we play a healthy role in building up the entire sector and fostering development.

Both the microfinance literature and our interview data thus point to a negative relationship between an MFO's size and financial performance and the amount of public funding it receives. While some have suggested that this pattern may not materialize in practice - and that public and commercial funders compete to invest in the same MFOs (e.g., Abrams \& Von Stauffenberg, 2007) - evidence for these claims is based on limited data and has not been subjected to empirical testing. As such, we predict the following: 
Hypothesis 2. Within a country, the (a) size and (b) financial performance of an MFO is negatively associated with the amount of loans it receives from public funders.

\section{Environmental Uncertainty and the Shifting Relationship between Logics and Action}

Our arguments thus far reflect a fairly faithful application of the logics perspective. However, this theoretical approach is limited in that it does not consider that firms which adhere to a logic may behave in different ways under different environmental conditions. Indeed, although we know that firms often operate in multiple jurisdictions, research on logics and practice change has focused on understanding temporal shifts within specific contexts. For instance, studies have shown that organizations may adhere to a logic but alter their behavior subtly over time due to learning (Feldman \& Pentland, 2003), drift (Clemens \& Cook, 1999), or mindful deviation (Lounsbury \& Crumley, 2007). These shifts are idiosyncratic, though, and unlikely to generate systemic practice changes unless successfully theorized as rational and appropriate in relation to a logic (Delmestri \& Greenwood, 2016; Reay, Goodrick, Waldorff, \& Casebeer, 2016; Smets, Morris, \& Greenwood, 2012). Another mechanism that may lead to systemic practice change is replacement of a field's dominant logic. Typically, this is a slow and conflict laden process through which challengers mobilize to shift the prevailing understandings about what is appropriate and desirable in a field (York, Hargrave, \& Pacheco, 2015). When successful, this creates pressure for firms to conform to new behavioral expectations (Haveman \& Rao, 1997; Rao et al., 2003). These pressures may also motivate a firm to replace managers with people who adhere to the new logic and its associated practices (Thornton \& Ocasio, 1999).

While it is useful to understand how organizational behavior patterns can shift as the practices associated with a logic change, or a new logic ascends within a field, cross-sectional contextual contingency is arguably just as important in settings like ours where funders are active across diverse nations. Indeed, there is a growing recognition in the literature that the practices associated with a logic may be variously effective in different contexts (Vasudeva et al., 2013). Studies have also shown that as practices diffuse, local firms often alter them in patterned ways 
to increase their fit with the local environment (Boxenbaum \& Battilana, 2005). Taken together, this work suggests that firms may be motivated to alter their behavior in response to contextual contingencies and that, within a given context, such behavioral shifts may be patterned rather than idiosyncratic. While this work has not considered that firms which adhere to a logic might behave differently in different contexts, we suggest this extension can be made by linking the logics perspective to research on environmental uncertainty.

Whereas institutional scholars have focused on how firms respond to changing notions of appropriate behavior (e.g., Thornton \& Ocasio, 1999), studies of uncertainty examine how firms react when the environment changes in unpredictable ways (Child, 1972; Thompson, 1967). This work suggests that uncertainty disrupts the link between a firm's actions and expected outcomes, casting doubt on the efficacy of previous strategies (Audia et al., 2000). Resource providers may also have trouble with inferences about a partner's future performance in such situations because cause and effect become difficult to disentangle (Davis et al., 2009; Haunschild \& Miner, 1997). These factors create an impetus for firms to change their behavior in an attempt to deal with the specific uncertainty being faced (Beckman, Haunschild, \& Phillips, 2004; Pfeffer \& Salancik, 1978). As logics function as the lens through which decision-makers perceive and respond to external stimuli (Almandoz Rios, 2014), we expect that firms will alter their behavior in response to uncertainty and do so in ways they consider appropriate in relation to their orienting logic.

In microfinance, this means that how different types of funders go about pursuing their interests may differ based on the level of uncertainty in the nations where they operate. Because most MFOs are located in developing nations where there are varying levels of political and financial uncertainty, this is an important issue (Ault \& Spicer, 2014; Mair et al., 2012). We argue that the practices deemed appropriate according to both financial and development logics will shift as these two types of uncertainty increase, affecting the MFO attributes that a funder attends to and values when extending loans. 
Political uncertainty. Countries have their own specific rules and regulations with regard to investments. These rules, and a nation's political environment more broadly, are the outcome of a negotiated process whereby various interest groups negotiate, lobby, and otherwise seek to influence policymakers. The degree of uncertainty in this process is largely a function of the formal policymaking structure, which, in emerging economies, often lacks the requisite checks and balances to achieve political stability (Henisz \& Delios, 2004). Political uncertainty thus reflects the possibility that political decisions or events in a country will affect the behavior or ownership of organizations in ways that negatively affect investment returns (Howell, 2001).

There are two interrelated features of political uncertainty in a country that are germane to capital funders. The first is the quality of the political-institutional infrastructure necessary to facilitate business transactions. For example, regulations around property rights and contract enforcement provide assurances that asset ownership is respected by the law and that legal mechanisms are in place to ensure that contractual obligations are met. The second factor is a government's ability and willingness to change these regulations. For example, the ability of a faction to impose radical changes in a nation's political environment is limited by the presence of an impartial judiciary, democratic accountability, and bureaucratic quality. The absence of religious and military leaders from politics, lower levels of religious and ethnic tensions, and minimal levels of armed conflict are also related to political stability (Ramady, 2014). These conditions provide businesses with greater assurance that potentially harmful policies must pass through a process of checks and balances and build investor confidence by ensuring that the "rules of the game" in a nation are unlikely to change capriciously (Henisz, 2000; Li, 2009).

Financial uncertainty. In addition to political uncertainty, there is also uncertainty associated with a country's ability to finance its sovereign, commercial, and trade obligations. For example, as the amount of foreign debt increases relative to the size of the economy, a country's ability to repay its debts declines (Soussanov, 2002). When this happens, a nation is 
more apt to face financial crises such as recession and/or interest rate spikes (Arellano, 2008). Loan defaults are also often accompanied by exchange-rate instability, currency devaluations, and inflation, each of which has been shown to deter investment (Allayannis \& Weston, 2001; Geczy, Minton, \& Schrand, 1997). Supporting this, research has shown a link between financial stability and the investment returns achieved by foreign subsidiaries in a country (Click, 2005), as well as the future expected returns of domestic firms (Erb, Campbell, \& Viskanta, 1996).

\section{Commercial Funders and Financial Logic under Uncertainty}

Although commercial funders will likely demur from entering highly volatile countries, most recognize that investing in MFOs involves being active in nations with varying amounts of political and financial uncertainty (BlueOrchard, 2015; MicroRate, 2013). There is still the issue for funders, though, of how to respond if uncertainty rises in a nation where they are active. One option is simply to exit. Yet, in the microfinance context, this option is unlikely to be attractive. Commercial funders dedicate considerable time to building expertise and relationships in a focal country; many also have local offices with employees who monitor their national investments (BlueOrchard, 2015; Lützenkirchen et al., 2012). These are significant commitments and do not transfer easily to other contexts. Exiting a nation may also make reentry difficult when uncertainty recedes. Reflecting this, a fund manager told us the following:

If a country where we have a position starts to become more uncertain with regard to the economic or political climate, we start to get nervous. We're not going to pull out unless absolutely necessary [though] ...you start to look like the big bad capitalist guys if you just leave. It would make it hard for us to come back and we want to avoid that.

With this in mind, we expect that commercial funders will pursue financial returns under uncertainty by shifting their lending behavior. To this end, studies have found that uncertainty creates ambiguity about the link between an organization's past and future performances, as strategies that create strong performance in one environment may be ineffective in other contexts (Audia et al., 2000). Moreover, Davis et al. (2009) found that many strategies produced strong performance in stable environments but only a few remained effective when uncertainty 
increased. Studies also suggest that successful organizations can be reluctant to make strategic changes (Boeker, 1997; Prahalad \& Bettis, 1986), and this is problematic when the environment changes. For example, Audia et al. (2000) found that greater success leads firms to persist with past strategies after major environmental change, negatively affecting subsequent performance.

As a consequence of past performance losing predictive validity in uncertain contexts, studies suggest that resource providers are apt to shift their attention to visible, easy-to-evaluate quality signals such as size and status (Haunschild \& Miner, 1997; Podolny, 1994) that act as proxies for organizational stability (Geroski et al., 2010). The bigger resource endowments of large organizations may also help them to weather uncertainty and successfully alter their strategies in response to environmental changes (Dobrev, Kim, \& Carroll, 2003). This line of reasoning is evident in the practitioner literature on microfinance, where authors have suggested that MFO size creates a buffer against liquidity risks (Gonzalez, 2010), and that in uncertain environments "asset managers [focus] their efforts on risk management and...tightening their investment policies...[many move] up-market” (Glisovic \& Reille, 2010).

This interpretation was echoed by the commercial funders we spoke to. Discussing his firm's response to uncertainty, an investment officer told us "we're going to shift our local focus to less risky [MFOs]...big [MFOs] tend to be pretty stable; they're better bets to ride out adversity, so we will be more interested in them." Another said, "If a nation becomes more volatile, we'll certainly look at adjusting our position... when you don't know how strategies are going to play out, and what will be effective, size and reputation make a big difference, and these are highly correlated." Clearly linking these behavioral shifts to the application of financial logic, a fund manager told us the following:

We need to preserve our [financial] position.... When things get turbulent we change how we weight different factors.... The bottom line is that size becomes really important. You don't know what's going to work and what isn't. A larger [MFO] is more likely to be stable, a stronger institution. All other indicators become really subjective and hard to draw inferences from. 
As such, we expect that when political and financial uncertainty in a country rise, investors who adhere to financial logic will focus more on the size of potential fund recipients and less on past performance, as doing so should reduce risk and increase the prospect of preserving a return on capital. ${ }^{6}$ Accordingly, we predict the following:

Hypothesis 3. When (a) political uncertainty or (b) financial uncertainty in a country increase, the relationship between MFO size and commercial funding will become more positive.

Hypothesis 4. When (a) political uncertainty or (b) financial uncertainty in a country increase, the relationship between MFO financial performance and commercial funding will become less positive.

\section{Public Funders and Development Logic under Uncertainty}

We expect that public funders will also shift their behavior when a nation becomes more uncertain and do so in ways that they view as consistent with development logic. This means that, as with commercial funders, exit is unlikely when a national environment changes. As a part of their development aims, many public funders are mandated to disperse a set amount of money in specific regions or countries (Goodman, 2007). Beyond this, pulling their capital would undermine efforts to build capacity and foster stability in a nation's microfinance sector. Indeed, public funders generally try to play a countercyclical role by expanding activities to prevent a credit crunch when a nation becomes volatile (Otero, 1999). Linking this to development logic, a government official told us "[public] funders try to stay committed to countries that are facing uncertainty; leaving would completely be against development principles."

However, in staying in a nation, public funders must consider the implications that uncertainty has for their development aims. While public funders are willing to accept higher levels of investment risk to pursue development aims, capital recovery is still important. This is related directly to development goals, particularly among the DFIs that comprise the majority of public microfinance funding. DFIs are endowed with sovereign funds, but these are typically not

\footnotetext{
${ }^{6}$ There are other ways in which a funder may manage potential investment risk, such as increasing interest rates or issuing shorter-term loans. We examine these possibilities in our supplementary analyses.
} 
replenished by the sponsoring government (Hoffman, 1998). As such, the ability of these funders to pursue ongoing development aims requires them to retain and grow their capital base (Griffith \& Evans, 2012). Government agencies also face pressure to show they are making responsible budget allocation decisions (Lancaster, 2008). Further, funders have a finite amount of capital to invest, and this means that development goals are arguably best pursued by funding MFOs that can endure adversity. This was supported by our interviewees, such as the government official who told us, "[public funders] need returns to continue investing. How do you do development [work] if you lose all your money?" Similarly, a DFI manager said, "If [our] investments default what good would that do for the sector? Development means an MFO has to be there tomorrow."

With this in mind, we expect that the attention of public funders will shift toward MFO size when uncertainty increases, as larger MFOs are more likely to be seen as able to weather uncertainty (Josefy et al., 2015). This was echoed by many of our interviewees, who rationalized a focus on larger MFOs by appealing to development aims. Said one, "When a country gets volatile...you need someone to prop up the cornerstone institutions...sad as it is to say, the little guys are going to be exposed...the top tier [MFOs] are going to be able to pay you back."

Delving further into the rationale for this shift, another DFI manager said this to us:

It makes sense from a development perspective that you would move to larger [MFOs] as a country gets volatile to make sure you're not getting too much exposure in your portfolio. If these guys go under, that's not good for the sector, and it's not good for us. The potential development impact is much higher for a larger, more stable [MFO] that is going to be around to help anchor the sector tomorrow than it is to [keep pumping] money into one that might get itself into a liquidity crunch if the country stays volatile.

Based on this, we predict the following:

Hypothesis 5. When (a) political uncertainty or (b) financial uncertainty in a country increase, the relationship between MFO size and public funding will become less negative.

As we argued above, an MFO's financial performance is not likely to be an investment consideration among public funders in stable environments. Because past performance is a lessvalid predictor of future performance under uncertainty (Davis et al., 2009), we do not expect 
uncertainty to affect public funders' reliance on this consideration when making loan decisions.

\section{DATA AND METHODS}

To date, research on microfinance funding has been constrained by a lack of publicly available data. The Microfinance Information Exchange (MIX) and the Consultative Group to Assist the Poor (CGAP) both collect funding data but do not publicly disclose raw figures. Ratings agencies like MicroRate also collect data but only for a limited number of MFOs, most of which are in Latin America (Von Stauffenberg \& Rosas, 2011). Addressing this limitation, we were able to negotiate access to the raw MFO funding data collected by the MIX and compile a comprehensive database of microfinance funding.

The MIX is a nonprofit organization that acts as the major information provider on the microfinance industry. Founded by the World Bank, the MIX aims to provide comprehensive, objective, and relevant information about microfinance that is standardized and comparable across countries. MIX data are reliable and have been used widely in previous studies (e.g., Armendariz \& Morduch, 2010; Cull et al., 2009). As a part of its data-gathering efforts, the MIX began to track MFO funding data systematically starting in 2004. For each lending transaction, the MIX records the funder's name, type, country of origin, and amount of capital lent to the MFO in US dollars. In some cases, the interest rate and loan term are also recorded. Following conventional practice, and in consultation with the MIX, we categorized each funder as a commercial, public, or charitable organization, as reflected in Table 1.

The final dataset covers 891 MFOs in 92 countries that borrowed from 1,490 funders between 2004 and 2012. Based on our own calculations and estimates from our contacts at the MIX, this accounts for about 90 percent of the financing acquired by MFOs around the world over our analysis period. ${ }^{7}$ Our data thus comprise the most comprehensive, cross-sectional timeseries database of transactions between funders and MFOs that has been compiled to date.

\footnotetext{
${ }^{7}$ To calculate the coverage of our funding data, we divided the total outstanding loan amount per year by the total liabilities reported by MFOs in the MIX's publicly available financial data.
} 


\section{Variable Definitions}

Dependent variables. Using data from the MIX funding database, we constructed two outcome variables - commercial and public capital — that respectively capture the inflation adjusted logged amount of capital in USD acquired by a focal MFO from these funder types in a specific year. In cases where an MFO did not receive any loan dollars from either a commercial or public funder, we set the corresponding value to 1 prior to logging.

Independent variables. Our key independent variables are indexes that encompass multiple measures of both MFO size and financial performance. Unlike agencies that combine size, performance, and transparency indicators to form a single aggregate measure of MFO investment risk (MicroRate, 2013), we assembled separate indicators for each of these.

Exploratory factor analysis verified that the indicators load onto three distinct factors and should be analyzed separately. We describe each indicator in Table 2.

-----Insert Table 2 about here-----

To validate these exploratory findings, we performed a confirmatory-factor analysis with maximum-likelihood estimation procedures. The expected three-factor solution was an excellent fit with the data $(\mathrm{RMSEA}=0.029, \mathrm{CFI}=0.981, \mathrm{TLI}=0.969)$, and all factor loadings were significant at the .001 level. Based on this, we generated factor scores that reflect the size, financial performance, and transparency of each MFO in our analysis. We include transparency as a control variable because we expect (and find) that it is similarly relevant to all funders.

At the country level, we included measures for political uncertainty and financial uncertainty based on data compiled by the International Country Risk Guide (ICRG). Used widely by researchers (e.g., Bekaert, Harvey, Lundblad, \& Siegel, 2014; Boubakri, Mansi, \& Saffar, 2013; Dell'Ariccia \& Marquez, 2010), the ICRG draws on 22 metrics and evaluates 140 countries in terms of their political, economic, and financial uncertainty. ${ }^{8} \mathrm{We}$ focus on the

\footnotetext{
${ }^{8}$ Note that ICRG calls these variables "risks." However, our consultation with the data source suggests that ICRG does not follow the scholarly distinction between uncertainty and risk. In fact, the way ICRG approaches political
} 
political and financial uncertainty scores of the countries in our database because the measure of economic uncertainty is highly correlated with the measure of financial uncertainty $(p=.77)$ and overlaps with various control variables that we discuss below (e.g., GDP per capita).

Political uncertainty comprises 12 measures that capture the degree of political stability in a country: government stability, socioeconomic conditions, investment profile, internal conflict, external conflict, corruption, military in politics, religious tensions, law and order, ethnic tensions, democratic accountability, and bureaucracy quality. The variable is measured on a 100-point scale, with higher values indicating lower uncertainty. Hence, we reverse-coded it so higher values denote greater uncertainty. Financial uncertainty reflects a country's ability to meet its commercial and trade debt obligations. It is constructed as a 50-point scale and includes five components: foreign debt as a percentage of GDP, foreign debt service as a percentage of exports, current account as a percentage of exports of goods and services, net international liquidity as months of import cover, and exchange-rate stability. Again, we reverse-coded this variable. To test hypotheses 3, 4, and 5, we interacted MFO size and financial performance with the two country-level uncertainty variables using mean-centered values.

Control variables. Commercial and public capital funding may relate to several factors not included in our hypotheses. To account for the overall wealth of the country where an MFO resides, we include a measure of GDP per capita (logged). Microfinance funding may also be influenced by the prevalence of aid already being received in the MFO country. Therefore, we controlled for net official development assistance (Net ODA) as a percentage of gross national income (Lacalle \& Alfonso, 2011). Given that the degree to which a nation is economically integrated into the world society likely influences its ability to attract capital, we controlled for economic globalization, which is an index measure based on a country's trade and investment flows, portfolio investment, income payments to foreign nationals, import barriers, tariff rates, 
international trade taxes, and capital account restrictions. These data are from Dreher (2006) and the measure forms a 100-point scale in which higher values indicate greater globalization.

In light of past research that has suggested cross-country similarities may affect microfinance funding flows (Garmaise \& Natividad, 2013), we controlled for three types of lender-MFO country distance: economic (differences in economic development and macroeconomic characteristics), financial (differences in financial-sector development), and political (differences in political stability, democracy, and trade-bloc membership). Using data collected by Berry and colleagues (2010), we first calculated the average of each distance between the MFO country and all its lender countries, which generated an average score, respectively, for economic, financial, and political distance for each MFO-year. Because the three distance variables are highly correlated $(p=0.52-0.74)$, we took an overall average across all three and included it as a control for country distance in the models.

In addition, one alternative explanation for our hypothesized results is that increasing financial and political uncertainty affects the composition of a country's microfinance sector such that smaller, less-sustainable MFOs fail or are acquired, leaving only larger MFOs to receive funds. To account for this possibility, we included three variables based on the composition of a country's microfinance sector. To control for sector size and growth, we included a measure of the number of new MFOs founded per country-year as well as the number of active MFOs. We also included a measure of microfinance industry concentration for each nation, which is calculated using a Herfindahl index based on each MFO's share of assets in the sector. These variables reflect the vibrancy of a country's microfinance sector, how many MFOs may actively be seeking funding, and whether the industry is consolidating or otherwise becoming more concentrated. The measures were calculated using the MIX data.

We also include a number of MFO-level controls. Because nonprofit MFOs can accept charitable donations and nongovernmental organization (NGO) grants- - which are not included 
in our data - they may be less likely to seek loans (Gonzalez, 2010). Thus, we control for nonprofit status (coded as "1" for nonprofit). We also control for MFO age in years and efficiency, which is the logged number of borrowers served per loan officer of each MFO, a standard measure in the microfinance literature (MicroRate, 2013). As noted above, we also controlled for an MFO's transparency. As detailed in Table 2, the variable is based on an MFO's Diamond Score from the MIX, which rates the quality and level of transparency in financial reporting, and its regulatory status, which is associated with specific reporting requirements.

Each covariate is lagged one year, with the exception of MFO age. Descriptive statistics and correlations are presented in Table 3. We checked for possible multicollinearity in our model by conducting a variance inflation factor (VIF) test. The maximum VIF score obtained was 7.82 and the mean VIF was 2.72, both below the commonly used threshold value of 10 (e.g., Kennedy, 1992), indicating that multicollinearity was not a concern. ${ }^{9}$

-----Insert Table 3 about here-----

\section{Analytic Approach}

In this study, the unit of analysis is the MFO, and the unit of observation is the MFOyear. Our primary dependent variables are commercial and public capital. Each MFO for each year, therefore, has a separate observation for each dependent variable. Based on this, we ran ordinary least squares (OLS) regression models for the amount of commercial capital received per MFO-year, and for the amount of public capital received per MFO-year. All models include country-fixed effects to control for unobserved heterogeneity at the country level and to isolate cross-MFO differences in capital acquisition. A fixed effects model accounts for a country’s unobserved characteristics that do not vary over time that may affect MFO funding. This specification is achieved by subtracting the values of each observation from the country mean, removing all between-country differences and leaving only the within-country variation to be

\footnotetext{
${ }^{9}$ High VIFs are not unusual with the inclusion of interaction variables as the correlations between variables and their interaction terms are high by design. In this case, multicollinearity does not have serious adverse consequences.
} 
explained by the covariates (Wooldridge, 2006). Year-fixed effects were also included to control for any unobserved changes in the macro environment that might affect MFO funding over time. For robustness, we also analyzed the data using different model specifications, which we discuss in our section for robustness checks and supplemental analyses.

\section{RESULTS}

We present the results of our OLS analyses of commercial and public capital acquired by MFOs in Table 4. In model 1, we include only the controls. In models 2 through 8 , we test our hypotheses. Model 2 includes the two hypothesized measures of MFO risk: size and financial performance. Models 3 and 4 add the interaction between political uncertainty and size and financial uncertainty and size, respectively. Model 5 includes both size interactions. Models 6 and 7 look at the interactions between political uncertainty and performance and financial uncertainty and performance, respectively. Model 8 contains both performance interactions.

As shown in model 1, both commercial and public funders loan less money to nonprofit MFOs as compared to for-profit ones. This is consistent with research that suggests nonprofit MFOs may rely more heavily on other forms of funding, such as charitable grants (Gonzalez, 2010). There is also a positive relationship between commercial and public funding and MFO age and transparency. Notably, the positive impact of transparency on commercial capital becomes insignificant when MFO size and financial performance are also included in the model. This may reflect an effort among public funders to offset some of the risks associated with funding smaller and less financially strong MFOs by ensuring that those they do lend to have more transparent reporting. There are also a number of differences between commercial and public funders. In nations where economic globalization increased, MFOs received less money from public funders. MFOs in countries with more MFOs received fewer loan dollars from public funders, while MFOs in countries with more MFO foundings received more loan dollars from commercial funders. MFOs also tend to acquire more commercial capital from lenders 
based in more economically, financially, and politically distant countries. This may reflect commercial capital flows from more developed countries (e.g., United States and Netherlands) to developing countries. In our supplemental analyses, we further investigate whether our results remain after accounting for the home-country effect of lenders.

Model 1 also shows how country uncertainty affects commercial and public capital flows to a nation's microfinance sector. As expected, there is little evidence of capital flight (i.e., rapid outflow of capital from a nation due to unfavorable events). Financial uncertainty is negatively and significantly related to commercial funding, but there is no effect for political uncertainty. Neither political nor financial uncertainty has a significant impact on public funding.

Hypothesis 1 predicted that commercial capital will be positively related to an MFO's (a) size and (b) financial performance. Results from model 2 support both predictions and show that commercial funders invest in MFOs that are larger and financially stronger. Holding all covariates at their mean level, the predicted value of commercial investment is $\$ 2,495,500.83$. A one standard deviation increase in MFO size (0.97) raises the predicted value of commercial investment by about $128 \%(\$ 3,194,241.06)$, while a one standard deviation increase in financial performance $(0.43)$ raises the predicted value by about $33 \%(\$ 823,515.27)$.

Hypothesis 2 predicted that public funders will lend to MFOs that are (a) smaller and (b) less financially strong. The coefficient for MFO size is in the predicted negative direction but is not significant. Though the results are consistent with the argument that public funders are not sensitive to MFO size in their investment decisions, hypothesis $2 \mathrm{a}$ is not supported. Our results provide direct support for hypothesis $2 \mathrm{~b}$, though, and show that public funders are more likely to invest in MFOs with weaker financial performance. Holding all covariates at their mean level, the predicted value of public investment is $\$ 53,103.60$. A one standard deviation increase in financial performance $(0.43)$ lowers the predicted value by about $51 \%(\$ 27,082.84)$. While there is anecdotal evidence of commercial and public funders competing to invest in the same MFOs 
(e.g., Abrams \& Von Stauffenberg, 2007), our results suggest that, on average, commercial capital goes to larger, financially stronger MFOs, while public capital goes to MFOs of varying sizes that have relatively weaker financial performance. Thus, per the logics approach, in stable environments commercial and public funders appear to be guided by different considerations and channel money to different MFOs.

Hypothesis 3 predicted that when (a) political uncertainty and (b) financial uncertainty in a country increase, the relationship between commercial funding and MFO size will become more positive. Hypothesis 5 predicted a positive interaction between MFO size and (a) political uncertainty and (b) financial uncertainty for public funders, such that the relationship between public funding and MFO size will become less negative. The results from models 3 and 4 show positive and significant interactions for political uncertainty and size and financial uncertainty and size for both commercial and public funders, supporting hypotheses 3 and 5 . Yet as models 2 and 3 indicate, the main effect of MFO size was not significant for public funders. Hence, rather than the effect becoming less negative, the relationship between size and public capital becomes positive as political uncertainty increases. Similarly, model 4 reveals that the relationship between MFO size and public capital also becomes positive as financial uncertainty increases. In model 5, the interaction of size and political uncertainty is insignificant for public funders when both sets of interactions are included. Still, as we expected, the results overall show a clear pattern of capital flowing from both funder types to larger MFOs as country uncertainty increases.

To gain more insight into the interaction effects, we plotted the significant interactions based on models 3 and 4 in Figure 1. We also followed Aiken and West's (1991) procedure and conducted simple slope tests for significant interactive terms. In separate equations, we split the two uncertainty variables into two groups - low (below the mean) and high (above the mean) and estimated the effect of MFO size and on both commercial and public capital for both levels. 
We find that MFO size significantly predicts commercial funding when political uncertainty is high (simple slope $b=3.036, p<0.001)$ and when it is low $(b=1.011, p<0.001)$. MFO size also significantly predicts public funding when political uncertainty is high (simple slope $b=$ $1.829, p<0.05)$, but not when it is low $(b=-0.505, p>0.10)$. We similarly find that MFO size significantly predicts commercial funding when financial uncertainty is high (simple slope $b=$ $3.365, p<0.001)$ and when it is low $(b=1.037, p<0.001)$. MFO size also significantly predicts public funding when financial uncertainty is high (simple slope $b=8.298, p<0.001$ ), but not when it is low $(b=-0.735, p>0.10)$.

In models 6 through 8, we find mixed support for hypothesis 4, which predicted that when political uncertainty and financial uncertainty in a country increase, the relationship between commercial funding and MFO financial performance will become less positive. As political uncertainty increases, the financial performance of MFOs becomes a less heavily weighted criterion in commercial funders' lending decisions. We do not observe a similar effect for financial uncertainty, however. This may be due to the fact that MFOs with strong past financial performance are well-positioned to deal with the volatility introduced by domestic inflation and currency devaluations (which can be partly managed through local currency loans from a funder), whereas the more fundamental changes to the "rules of the game" that may accompany political uncertainty (North, 1991) might make it difficult to predict future financial performance from the past (Haunschild \& Miner, 1997). As expected, the financial performance of MFOs does not affect public funders under higher country uncertainty.

In Figure 2, we plot the significant interaction based on model 6. We again ran a simple slopes test by splitting political uncertainty into a low and high group as described above and estimating the effect of financial performance on commercial capital. Results show that financial performance is not significantly related to commercial funding when political uncertainty is high $(b=-0.741, p>0.10)$, but it is when political uncertainty is low $(b=1.733, p<0.001)$. 
-----Insert Table 4 and Figures 1 and 2 about here-----

\section{Robustness Checks and Supplementary Analyses}

We conducted a number of robustness checks and ran a variety of supplementary models to help rule out alternate explanations and bolster our findings. The results of these analyses can be viewed at https://mfifunding.wordpress.com.

Alternate modeling approaches. We took steps to ensure our findings were robust to alternate modeling approaches. First, it is possible that the funds an MFO receives from one funder-type (e.g., public) may correlate with those it receives from another (e.g., commercial). If true, separate equations might lead to inefficient estimates, with disturbances contemporaneously correlated across equations (Zellner \& Huang, 1962). To account for this possibility, we used seemingly unrelated regression, which enables joint estimation of multiple regression models, each with its own error term, and thus corrects for the possibility of correlation among error terms (Kennedy \& Fiss, 2009). Our findings are robust to this alternate approach.

There may also be concerns with modeling multilevel data such as ours (i.e., MFOs within nations) using OLS regression because the standard errors of observations at lower levels of analysis may not be independent. To ensure this did not bias our results, we used hierarchical linear regression, or multilevel mixed-effects models (HLM). Results are consistent with our reported models. However, while this approach explicitly accounts for the multilevel nature of our data, we chose to report OLS models as our main analysis for three reasons: (1) OLS is more commonly used than HLM, which eases interpretation of our results among a broader readership; (2) the use of country-fixed effects in OLS helps to address non-independence of standard errors across levels of analysis, and (3) standard HLM models do not allow us to control for potential unobserved country-level variables as with fixed effects OLS regression (Chaplin, 2003).

Alternate dependent variables. Another potential issue is that, while there is precedent for analyzing overall investment levels in both the management (e.g., Pahnke et al., 2015; Wry et 
al., 2014) and microfinance literatures (Gonzalez, 2010; Sapundzhieva, 2011), there are other potential ways to measure funding. We ran models with alternate dependent variables to ensure our results were robust to different measures. First, the practical value of a loan may be related to its term (Fama \& French, 2012). For example, a \$1 million loan may have different implications if its repayment term is two versus ten years. While data for loan term is not as complete as for loan amount, we constructed an alternate variable where we divided the amount of each loan by its term in years. Despite the data loss, results using this variable were similar to our reported findings. Second, while there are good reasons to expect funders respond to uncertainty by shifting which MFOs they lend to, the finance literature points to other potential responses; namely charging higher interest and/or reducing the length of the loan term (Fama \& French, 2012). While data for these measures are sparse, we ran models using interest rate and loan length as dependent variables. The results are more suggestive than authoritative, but there is little to suggest these are tools that either funder-type typically uses in response to uncertainty.

Alternate influences on funder behavior. In developing our approach, we argued that it is important to attend to the ways that environmental uncertainty affects organizational behavior. We recognize, however, that the environment includes unmeasured features that may affect how an organization acts. This issue is accounted for, in part, by our use of country-fixed effects, as this addresses unobserved variance in each nation where loans are made. Still, many funders are not based in the countries where they make loans, and this means that their behavior may also be affected by home-country influences. As a check, we ran separate models comparing funders in the United States and the Netherlands - the nations with the most microfinance funders - to all other foreign funders. We do not observe any systematic differences across these funders, thus suggesting that home-country influences do not affect our results in a meaningful way.

In addition, while the microfinance literature suggests that commercial and public funders comprise meaningful groupings, as Table 1 shows, there are subtypes therein. We took steps to 
ensure that subgroup heterogeneity was not a concern in our analysis. Models that distinguish between different types of commercial and public funders show that, while overall patterns are mostly similar across subtypes, there are some differences. Most notably, government funders differ from DFIs in that they seem to favor larger MFOs. Still, we urge caution when interpreting these results as the number of government funders in any one nation is small, making countryfixed effects models unstable. In comparison, there are many DFIs present in most nations, and these collectively account for a much greater portion of overall funding (Sapundzhieva, 2011).

Also, while there are good theoretical reasons - supported by our interviews - to expect that the behavioral patterns we observe are a result of funders acting in logic-consistent ways in settled versus uncertain contexts, an alternate explanation is that they are changing their logics. Studies suggest this might happen if there is a field-level shift in expectations for how certain types of firms should behave, or if individual firms are motivated to replace their leadership with people who adhere to a different logic (Haveman \& Rao, 1997; Thornton, 1999). We see little evidence for either. Many funders operate in multiple countries, and most investment funds, private equities, and DFIs are based in the United States or Western Europe (Gonzalez, 2010). We found nothing in the microfinance literature to suggest that expectations for how commercial or public funders should behave shifted over our analysis period at either the field-level, or individually across countries. It seems equally unlikely that funders would be motivated to alter their overall interests in response to uncertainty in individual host countries.

Still, we took steps to empirically rule out this alternate explanation. As the concern with logic change is primarily relevant for public funders, we focused our analysis on them. First, we ran funder-fixed effects models comparing public funder behavior in the most (top half) and least (bottom half) uncertain nations in our analysis. As expected, we see a large difference in the coefficients for MFO size. These results suggest that behavior is being driven by country-level factors, rather than a logic shift at the funder-level. As a further check, we also ran models with 
fixed effects at the funder-MFO dyad level. This specification analyzes temporal differences in the relationship between a given funder and a given MFO. Results show a positive significant interaction between MFO size and uncertainty, and a modestly significant negative interaction between MFO performance and uncertainty. This shows that uncertainty influences specific MFO investment relationships over time, providing additional evidence against logic change.

Finally, it is possible that MFO size and performance capture management quality, which might suggest a different interpretation of our results. This issue is partially accounted for through the inclusion of MFO transparency in our models, as there is evidence that financial reporting quality is associated with professional management (Armendariz \& Morduch, 2010). Still, we took the additional step of investigating this using a survey that we distributed to each MFO in our analysis. The goal was to collect data on each MFO's management quality by asking "How important are the following to your organization: (1) formal rules and procedures, (2) internal financial controls, (3) employee training, (4) internal efficiency, (5) risk management, and (6) personal accountability?"10 In sum, we received 193 responses and found no systematic response bias (i.e., size, performance, and transparency of responding and nonresponding MFOs were similar). We used this data to build an additive index of MFO management quality. While the small sample size precluded using the variable in formal models, the measure is not highly correlated with MFO size (-.04) or performance (-.13). Thus, while management quality may be a relevant investment consideration, it appears to be distinct from our key independent variables.

Implications of our findings. It is important to understand the consequences of our finding that funding increasingly flows to large MFOs when a nation becomes more uncertain. An obvious implication is that smaller MFOs may find it difficult to finance their loan portfolios even if they are financially sustainable, which negatively affects the health of these organizations and can undermine competition in a country's microfinance sector (Abrams \& Von Stauffenberg,

\footnotetext{
${ }^{10}$ The practitioner literature suggests that these are key factors that reflect an MFO's commitment to professional management (Ikeanyibe, 2009; MicroRate, 2013).
} 
2007). There are also concerns about capital flowing primarily to larger MFOs because some have suggested these organizations are less committed to social outreach (Frank, 2008).

To test this directly, we use generalized least squares models with MFO-level fixed effects to test the relationship between MFO size and two measures commonly used in the microfinance literature to assess social outreach: average loan size, which captures the extent to which MFOs target higher-income clients who can afford to borrow larger amounts; and the proportion of borrowers who are women, which captures an MFO's willingness to target the most at-risk population of potential clients (Cull et al., 2009; Roberts, 2013). Results are shown in Table 5 and show that, on average, larger MFOs engage in significantly less outreach. The shifts we observe in funder behavior may thus have negative effects on a nation's microfinance sector. When financial uncertainty and political uncertainty increase, loans flow to larger MFOs and away from others that are more highly committed to poverty reduction.

-----Insert Table 5 about here-----

\section{DISCUSSION}

Over the past three decades, microfinance has emerged as an important tool to combat poverty. While research has focused primarily on the downstream impacts of lending to the poor (e.g., Banerjee et al., 2015), we analyze upstream funding flows. Doing so is important because most MFOs are not self-financed but rather intermediaries that aggregate external funds and disperse them as loans (Sapundzhieva, 2011). Although funding is a critical component of the microfinance ecosystem, scholarly inquiry in the area has been limited. Academics have made important inroads into enhancing our understanding of microfinance funding by studying crossnational capital flows and interest rates (Garmaise \& Natividad, 2010; Tchuigoua, 2014). Practitioner research has used largely anecdotal evidence to argue that funders compete to invest in the largest, financially strongest MFOs (Von Stauffenberg \& Rosas, 2011).

By leveraging the most inclusive database that has been assembled to date, our study 
provides the first systematic global analysis of microfinance funding. We apply insights about institutional logics to make baseline predictions about lending differences among commercial and public funders. We then extend this to consider how the types of behavior that a logic produces might shift in the face of growing uncertainty. As expected, we find that commercial and public funders lend to different types of MFOs in stable environments but that this difference recedes as the external environment becomes less predictable. Under such conditions, both types of funders focus more heavily on MFO size, whereas financial performance becomes less important as an investment criterion. Smaller MFOs are thus less likely to attract funding, which has potentially negative implications for the level of competition, service, and social outreach in a nation's microfinance sector (Von Stauffenberg \& Rosas, 2011; Wiesner \& Quien, 2010).

\section{Theoretical and Practical Implications}

Implications for organizational theory. Theoretically, our primary contribution is to advance knowledge about the link between institutional logics and organizational practices. As numerous studies have shown, the logics perspective helps to explain organizational action by recognizing that shared beliefs about appropriate behavior - or cultural influences — are not just externally imposed (Scott, 2001) but are also internalized by decision-makers (Thornton et al., 2012). As a result, firms that adhere to the same logic tend to behave in similar ways. Yet, while this work has enhanced our understanding about why organizations within the same field or industry act differently, a focus on singular contexts has contributed to theoretical blind spots related to the influence of broader contextual forces that may affect the types of behavior that are associated with a logic. Indeed, despite recognizing that firms often operate across multiple geographies, most studies have assumed that logics are linked to specific practices (Vasudeva et al., 2013). Some have suggested that this link is not always so tight and that practices may change due to learning (Feldman \& Pentland, 2003), drift (Clemens \& Cook, 1999), or active deviation (Lounsbury \& Crumley, 2007). Still, behavioral shifts are theorized as idiosyncratic 
and unlikely to generate systemic change unless actors mobilize to alter a field's dominant logic (Rao et al., 2003), frame contested practices as legitimate (Smets et al., 2012), or replace a firm's top managers (Thornton \& Ocasio, 1999).

Our study adds insight by showing that organizations that adhere to a given logic may behave in reliably different ways depending on the environment they are in. Specifically, we connect the logics perspective with research on how firms respond to uncertainty in the external environment. We note that uncertainty disrupts the link between actions and expected outcomes and thus creates an impetus for behavioral change (Davis et al., 2009). As logics serve as the lens through which decision-makers interpret and respond to the external environment, we show that uncertainty leads to organizations altering their behavior in ways that are perceived as rational for pursuing their interests. As a result, the practices of firms that adhere to different logics may converge or diverge in different contexts. Our study therefore highlights the contextual nature of the link between logics and practices and helps sensitize scholars to outcomes that might be missed by applying the logics perspective alone.

In this way, we go beyond studies that have examined the influence of multiple logics and externally imposed institutional demands as sources of practice variation (e.g., Greenwood et al., 2011) and direct attention to the potential for material forces to mediate the influence of cultural ones. This hearkens back to early organizational research where scholars endeavored to map the features of the external environment (Emery \& Trist, 1965; Thompson, 1967) and suggests that this work is relevant to contemporary theoretical debates. Indeed, we show that by considering the material features of a firm's environment, further insight can be gained into how actors use logics as a resource to guide behavior, rather than conforming to specific behavioral precepts oblivious to contextual contingencies (Battilana, Sengul, Pache, \& Model, 2014; Pache \& Santos, 2013; Wry \& York, 2015). We anticipate that future research will work to deepen our understanding of the ways in which cultural and material influences work in tandem to shape 
organizational action. Further, while we focus on one facet of the external environment, our approach could be easily extended to consider how practices associated with a logic might differ across communities (Marquis \& Lounsbury, 2007), societies (Vasudeva et al., 2013), or industries (Thornton \& Ocasio, 1999), thus suggesting a broad range of research applications.

In addition, our study has implications for research on foreign aid which, for the most part, has focused on understanding aggregate funding flows between countries (e.g., Fleck \& Kilby, 2006). We show that organizational theory can help to derive novel insights by drawing attention to the interests and actions of the firms that provide these funds. This is important because a focus on overall funding flows says little about the uses and efficacy of aid dollars (Alesina \& Dollar, 2000). The substantive work of poverty reduction is done by organizations; examining how they are funded has the potential to yield more granular insights that link aid dollars to outcomes of interest. The application of institutional logics thus has the potential to extend our understanding of the dynamics of foreign aid by unearthing organization-level variance that is masked in country-level analyses. As such, our study suggests an important role for organizational theory in linking organizational decision-making to practices that directly affect societal welfare (see also Cobb, 2016; Tilcsik \& Marquis, 2013).

Implications for microfinance research. It is generally accepted that funders consider MFO size, financial performance, and transparency in their funding decisions. Yet, while studies have suggested that these attributes are differently attended to by commercial and public funders, there have been no systematic predictions about the nature of these differences. In this regard, the institutional logics perspective usefully directs attention to the varying bases of interest and action among different types of funders, and thus supports predictions about which MFO features are attended to and valued when making lending decisions. The logics perspective also supports predictions about how an organization's actions, but not interests, might change under different conditions, thus helping to reconcile conflicting claims about commercial and public funders 
being competitors rather than complements (Gonzalez, 2010; Von Stauffenberg \& Rosas, 2011).

A focus on country-level uncertainty also helps to illuminate the influence of national context on microfinance sector health and efficacy. Environmental uncertainties are recognized as important in microfinance funding decisions (BlueOrchard, 2015; Kiva, 2015), but this assumption has not yet been examined empirically. Our findings suggest that smaller MFOs will find it difficult to access funding as uncertainty rises, which can strain an MFO's cash position and increase its risk of failing (Reille et al., 2011). Further, when capital flows into larger MFOs that engage in less social outreach, a smaller portion of external funding can be expected to reach very poor and female borrowers. This is especially problematic when uncertainty in a nation rises, as this disrupts labor markets, creates unforeseen expenses, and reduces purchasing power, all of which increase the likelihood of vulnerable groups falling into poverty (Adger, 2006; Sen, 1981). There is also evidence that entrepreneurship increases in volatile environments (George, Kotha, Parikh, Alnuaimi, \& Bahaj, 2015), furthering the need for microfinance. Our findings thus suggest that rising uncertainty creates more need for microfinance but works through the logics of different funders to undermine outreach in the sector.

We also make an empirical contribution to microfinance research. To date, practitioners and ratings agencies have used composite measures that combine MFO size, performance, and transparency to organize MFOs into risk tiers (MicroRate, 2013; Sapundzhieva, 2011). We cast doubt on the empirical validity of this approach by showing that these factors do not correlate in a way that supports their integration. We also show that size and performance are differently weighted by commercial and public funders and that the importance of these variables shifts in different ways as a nation becomes more uncertain. The relationship between funding and MFO attributes is thus more nuanced and contextually dependent than what has been portrayed to date.

Practical implications. Our study also has implications for MFOs. In particular, results suggest that one way in which MFOs can maintain access to funding under uncertainty is to 
grow. Strategies such as organic growth, mergers, or extra-organizational linkages such as consortia or alliances may help an MFO buffer against rising uncertainty (Pfeffer \& Salancik, 1978). Such strategies may be difficult, though, especially in volatile environments. We looked for examples of these strategies in response to uncertainty, but did not find any instances in our data or in the practitioner literature. It may be wise, though, for an MFO to proactively form alliances or expand operations in placid environments as a hedge against future uncertainty. Also, unreported models suggest that transparent MFOs may receive more loans from commercial and public funders as uncertainty increases. ${ }^{11}$ Thus, improved financial reporting may be a cost-effective way for an MFO to stabilize resource flows under uncertainty.

Our study also has implications for public funders. While their individual actions may be consistent with development logic, the collective result of lending to larger MFOs as uncertainty rises is likely at odds with sector development. Given that the link between logics and practices is potentially fluid, this suggests that public funders should consider the collective outcomes of their behavior and work to redefine appropriate action in such contexts (Wry, Lounsbury, \& Glynn, 2011). In this regard, one option might be to collaborate and form a reserve capital pool that is dedicated to helping small and financially vulnerable MFOs weather uncertainty. This is not unprecedented, as a number of public funders banded together during the global financial crisis to seed a US\$500 million fund that targeted adversely affected MFOs (Reille et al., 2011).

Further, there may be public policy mechanisms that can help reduce the adverse effects of political and financial uncertainty on MFO funding. Because MFO loan default is the main investment risk for a funder, policies and initiatives that help reduce this risk may be an effective means by which smaller MFOs that are more focused on social outreach can still receive funding when environmental uncertainty increases. To the extent that foreign governments and aid agencies see development finance as valuable tool for supporting a nation's microfinance sector,

\footnotetext{
${ }^{11}$ These models are available to view at https://mfifunding.wordpress.com/supplementary-analyses/.
} 
offering loan guarantees or other forms of protection may help to inoculate funders against increasing uncertainty that would otherwise alter their investment behavior. Similarly, providing subsidized loan insurance to smaller MFOs may help these organizations weather environmental shocks that affect their ability to obtain capital and repay their loans. Host country governments may also offer such protections, through this may become challenging as they, themselves, are forced to deal with rising uncertainty. Thus, while loan guarantees and insurance systems may create moral hazards and adverse selection, careful initiatives may lower MFO investments risks, thereby contributing to stable investment flows and a healthy funding ecology amid uncertainty.

\section{Limitations and Future Research}

There are limitations to our study that highlight opportunities for future research. Empirically, our analysis is limited to debt financing and thus is not inclusive of all MFO funding. While the vast majority of funds are issued through loans, future studies should examine other types of investment, such as grants and equity. Also, because our data only track loans, we are unable to analyze funds that support capacity building and regulatory infrastructure in a nation's microfinance sector. Additional analyses will be possible as this data becomes available.

Further, while funding is a crucial part of the microfinance ecosystem, we recognize that its effects are contingent on a nation's capacity to regulate the microfinance sector (Ledgerwood et al., 2013). When safeguards are not in place to guard against over-borrowing by clients and unhealthy competition among MFOs, there is evidence that increased funding can have negative consequences. For instance, a glut of foreign capital contributed to a proliferation of Bosnian MFOs that competed with each other for business, issued progressively riskier loans, and made the sector susceptible to crisis (Reille et al., 2011). Thus, while uncertainty contributes to one set of challenges in microfinance funding, stable contexts may come with their own issues. Our findings should be interpreted with this consideration in mind.

Finally, while our analysis suggests that organizations shift their behavior in ways that 
they perceive as logic-consistent, other audiences may have a different interpretation. Indeed, there is evidence that some microfinance observers consider it 'mission drift' when public funders invest in large MFOs (Von Stauffenberg \& Rosas, 2011). While there are no data for us to examine this or its implications directly, it nonetheless points to interesting avenues for future research. Debates about mission drift are endemic to sectors where firms pursue both financial and social aims (Battilana \& Lee, 2014); our approach suggests this may be due to conflicting interpretations from internal and external audiences about what sorts of behavior are appropriate vis-à-vis a particular logic. We envision future research examining conflicts that arise, not just among groups that adhere to different logics but also among those that disagree over how to interpret the same logic. It would be interesting to study the challenges this presents for organizations, especially those pursuing pro-social aims.

\section{CONCLUSION}

Microfinance is a tool with the potential to make a meaningful contribution to global poverty reduction. Yet in their attempts to study the impacts of microfinance loans, scholars have largely overlooked the question of how these loans are financed. Building on and extending the institutional logics perspective and using the most comprehensive database of microfinance funding constructed to date, we show that commercial and public funders invest in different types of MFOs in stable environments but these differences retreat in potentially problematic ways as uncertainty increases and the need for microfinance intensifies. In so doing, the research presented here suggests that an organizational approach can usefully illuminate processes that shape the efficacy of microfinance as a way to address the grand challenge of global poverty. 
Table 1. Description and Statistics on Microfinance Funder Types

\begin{tabular}{|c|c|c|c|c|c|}
\hline $\begin{array}{c}\text { Funder } \\
\text { Type }\end{array}$ & Sub-types & $\begin{array}{c}\text { \# of } \\
\text { Lenders* }\end{array}$ & $\begin{array}{l}(\%) \text { of all } \\
\text { Loans }\end{array}$ & $\begin{array}{l}\text { Avg Loan } \\
\text { Size (\$US) }\end{array}$ & Illustrative Mission Statements \\
\hline \multirow{3}{*}{ Public } & & \multirow{3}{*}{244} & \multirow{3}{*}{$25.20 \%$} & \multirow{3}{*}{$\$ 1,085,163$} & $\begin{array}{l}\text { Combating poverty is [our] ultimate goal... as part of Spain's overall } \\
\text { foreign policy }\end{array}$ \\
\hline & $\begin{array}{l}\text { Government Programs and } \\
\text { Aid Agencies }\end{array}$ & & & & $\begin{array}{l}\text { [The organization] was established in } 1991 \text { to provide a focused } \\
\text { approach to the development of the micro enterprise sector by providing } \\
\text { or seeing to the critical inputs necessary for growth and sustainability }\end{array}$ \\
\hline & $\begin{array}{l}\text { Development Finance } \\
\text { Institutions }\end{array}$ & & & & $\begin{array}{l}\text { The Group is committed to alleviating poverty; promoting human } \\
\text { development; science and technology; Islamic economics; banking and } \\
\text { finance; and enhancing cooperation amongst member countries, in } \\
\text { collaboration with our development partners }\end{array}$ \\
\hline \multirow{3}{*}{ Commercial } & \multirow{3}{*}{$\begin{array}{l}\text { Financial Institutions } \\
\text { Private Corporations } \\
\text { Microfinance Investment } \\
\text { Funds }\end{array}$} & \multirow{3}{*}{990} & \multirow{3}{*}{$71.40 \%$} & \multirow{3}{*}{$\$ 1,212,751$} & $\begin{array}{l}\text { The Company seeks to achieve a commercially acceptable total return } \\
\text { that will meet or exceed historical returns achieved in the microfinance } \\
\text { area of the financial sector in emerging markets primarily via long-term } \\
\text { capital appreciation of portfolio investments }\end{array}$ \\
\hline & & & & & $\begin{array}{l}\text { To deliver superior returns to our investors by investing in companies } \\
\text { improving livelihood or providing access to essential services for low- } \\
\text { income communities in emerging markets }\end{array}$ \\
\hline & & & & & $\begin{array}{l}\text { The objective... is to promote microfinance as a viable investment option } \\
\text { through the development and management of a marketable portfolio of } \\
\text { high performing MFI funds, each offering "double bottom-line" returns } \\
\text { comparable with traditional capital market }\end{array}$ \\
\hline \multirow{3}{*}{ Charitable } & \multirow{3}{*}{$\begin{array}{l}\text { Foundations } \\
\text { Non-Governmental } \\
\text { Organizations } \\
\text { Individual /Peer-to-Peer } \\
\text { Lenders }\end{array}$} & \multirow{3}{*}{219} & \multirow{3}{*}{$3.40 \%$} & \multirow{3}{*}{$\$ 401,283$} & $\begin{array}{l}\text { Reaching out to the largest number of the poor and disadvantaged } \\
\text { households with appropriate microfinance services to enable them to } \\
\text { realize their untapped potentials of development through the network of } \\
\text { partner [MFO]s }\end{array}$ \\
\hline & & & & & $\begin{array}{l}\text { Through Access to Capital, we work to create economic opportunity for } \\
\text { people in emerging markets. By opening new doors to financial services }\end{array}$ \\
\hline & & & & & $\begin{array}{l}\text { and property rights, we're helping to foster entrepreneurial behavior, } \\
\text { economic activity, and job creation. Specifically, we focus on } \\
\text { microfinance, small-to-medium enterprise, emerging market ventures, } \\
\text { and property rights }\end{array}$ \\
\hline
\end{tabular}

* 37 of our funders are unknown types. 
Table 2. MFO Risk Dimensions and Empirical Indicators

\begin{tabular}{|c|c|c|}
\hline $\begin{array}{l}\text { MFO Risk } \\
\text { Dimensions }\end{array}$ & Indicators* & Description** \\
\hline \multirow[b]{3}{*}{ Size } & Number of Employees & Total number of employees of the MFO \\
\hline & Total Assets & Total of all net asset accounts \\
\hline & Number of Offices & $\begin{array}{l}\text { Total number of staffed points of service } \\
\text { and administrative sites used to deliver or } \\
\text { support the delivery of financial services to } \\
\text { microfinance clients }\end{array}$ \\
\hline \multirow{3}{*}{$\begin{array}{c}\text { Financial } \\
\text { Performance }\end{array}$} & Return on Assets & (Net Operating Income, less Taxes) / Assets \\
\hline & Operational Self-Sufficiency & $\begin{array}{l}\text { Financial Revenue/(Financial Expense + } \\
\text { Impairment Loss + Operating Expense) }\end{array}$ \\
\hline & Write-Off Ratio & Write Offs / Gross Loan Portfolio \\
\hline \multirow{2}{*}{ Transparency } & MIX's Diamond Score & $\begin{array}{l}\text { 5-point rating scale to evaluate the quality } \\
\text { and transparency of an MFO's financial } \\
\text { reporting ( } 5=\text { highest transparency) }\end{array}$ \\
\hline & Regulated Dummy & $\begin{array}{l}\text { A dummy variable indicating whether an } \\
\text { MFO is regulated by a state banking } \\
\text { supervisory agency }\end{array}$ \\
\hline
\end{tabular}

* All indicators are standardized before the factor analysis

** All descriptions follow the MIX's definitions 
Table 3. Descriptive Statistics and Correlation Matrix of Key Variables*

\begin{tabular}{|c|c|c|c|c|c|c|c|c|c|c|c|c|c|}
\hline \multicolumn{2}{|c|}{ Variables } & Mean & S.D. & 1 & 2 & 3 & 4 & 5 & 6 & 7 & 8 & 9 & 10 \\
\hline 1 & Commercial capital & 14.26 & 4.48 & 1 & & & & & & & & & \\
\hline 2 & Public capital & 8.77 & 7.29 & 0.13 & 1 & & & & & & & & \\
\hline 3 & GDP per capita & 7.30 & 0.87 & 0.01 & 0.06 & 1 & & & & & & & \\
\hline 4 & Net ODA ( $\%$ of GNI) & 3.23 & 4.95 & -0.10 & -0.08 & -0.53 & 1 & & & & & & \\
\hline 5 & Economic globalization & 53.39 & 12.42 & 0.09 & 0.01 & 0.53 & -0.05 & 1 & & & & & \\
\hline 6 & Country distance & 21.91 & 27.10 & 0.10 & -0.03 & 0.22 & 0.16 & 0.43 & 1 & & & & \\
\hline 7 & \# of active MFOs & 38.90 & 34.23 & 0.10 & 0.14 & -0.04 & -0.39 & -0.30 & -0.36 & 1 & & & \\
\hline 8 & \# of new MFO founded & 1.51 & 2.84 & 0.05 & 0.06 & -0.11 & -0.17 & -0.24 & -0.21 & 0.49 & 1 & & \\
\hline 9 & Industry concentration & 0.73 & 0.23 & 0.03 & 0.11 & -0.11 & -0.24 & -0.22 & -0.22 & 0.53 & 0.13 & 1 & \\
\hline 10 & MFO age & 13.73 & 8.90 & 0.05 & 0.10 & 0.09 & -0.15 & 0.04 & -0.10 & 0.01 & -0.18 & 0.11 & 1 \\
\hline 11 & Nonprofit & 0.52 & 0.50 & -0.20 & -0.14 & 0.14 & 0.03 & -0.03 & -0.03 & -0.16 & -0.13 & -0.04 & 0.14 \\
\hline 12 & Borrowers per loan officer & 5.64 & 0.60 & 0.08 & 0.11 & -0.08 & -0.17 & -0.30 & -0.21 & 0.30 & 0.14 & 0.21 & 0.18 \\
\hline 13 & Transparency & 0.04 & 0.09 & 0.29 & 0.17 & -0.13 & -0.10 & -0.08 & -0.08 & 0.18 & 0.10 & 0.09 & 0.13 \\
\hline 14 & Political uncertainty & 38.97 & 6.20 & -0.06 & 0.03 & -0.43 & 0.14 & -0.48 & -0.10 & -0.01 & -0.11 & 0.16 & 0.13 \\
\hline 15 & Financial uncertainty & 20.40 & 7.55 & -0.13 & -0.06 & -0.08 & 0.52 & 0.14 & 0.28 & -0.52 & -0.31 & -0.33 & 0.00 \\
\hline 16 & Size & 0.15 & 0.97 & 0.19 & 0.12 & -0.12 & -0.08 & -0.16 & -0.13 & 0.22 & 0.10 & 0.08 & 0.16 \\
\hline 17 & Financial performance & 0.10 & 0.43 & 0.11 & 0.03 & 0.05 & -0.10 & 0.07 & 0.05 & 0.00 & 0.03 & 0.03 & 0.08 \\
\hline 18 & Political uncertainty X Size & 0.62 & 9.18 & 0.06 & 0.04 & -0.07 & -0.02 & -0.07 & -0.02 & -0.03 & -0.03 & -0.02 & 0.14 \\
\hline 19 & Financial uncertainty X Size & -1.14 & 5.43 & -0.17 & -0.04 & 0.14 & -0.01 & 0.13 & 0.11 & -0.22 & -0.09 & -0.07 & -0.02 \\
\hline 20 & Political uncertainty X Financial performance & -0.12 & 4.20 & -0.02 & 0.00 & 0.07 & -0.07 & 0.05 & 0.01 & 0.00 & 0.04 & -0.04 & 0.06 \\
\hline 21 & Financial uncertainty X Financial performance & -0.27 & 3.01 & 0.03 & 0.05 & 0.07 & -0.14 & 0.00 & -0.03 & 0.10 & -0.02 & 0.04 & 0.07 \\
\hline
\end{tabular}

\begin{tabular}{|c|c|c|c|c|c|c|c|c|c|c|c|c|}
\hline \multicolumn{2}{|c|}{ Variables } & 11 & 12 & 13 & 14 & 15 & 16 & 17 & 18 & 19 & 20 & 21 \\
\hline 11 & Nonprofit & 1 & & & & & & & & & & \\
\hline 12 & Borrowers per loan officer & 0.05 & 1 & & & & & & & & & \\
\hline 13 & Transparency & -0.30 & 0.13 & 1 & & & & & & & & \\
\hline 14 & Political uncertainty & 0.06 & 0.19 & 0.09 & 1 & & & & & & & \\
\hline 15 & Financial uncertainty & 0.07 & -0.10 & -0.19 & 0.04 & 1 & & & & & & \\
\hline 16 & Size & -0.08 & 0.15 & 0.76 & 0.10 & -0.14 & 1 & & & & & \\
\hline 17 & Financial performance & 0.00 & 0.12 & 0.41 & -0.05 & -0.08 & 0.02 & 1 & & & & \\
\hline 18 & Political uncertainty X Size & 0.04 & 0.00 & 0.54 & 0.04 & -0.01 & 0.73 & 0.01 & 1 & & & \\
\hline 19 & Financial uncertainty X Size & 0.13 & -0.17 & -0.43 & -0.02 & -0.05 & -0.58 & 0.05 & -0.09 & 1 & & \\
\hline 20 & Political uncertainty X Financial performance & -0.01 & -0.01 & -0.11 & -0.09 & -0.04 & 0.01 & -0.33 & 0.05 & 0.01 & 1 & \\
\hline 21 & Financial uncertainty X Financial performance & -0.06 & 0.06 & 0.12 & -0.06 & -0.07 & 0.04 & 0.26 & 0.02 & -0.01 & -0.01 & 1 \\
\hline
\end{tabular}

*All correlations equal to or greater than 0.05 are significant $(\mathrm{p}<.05)$. 
Table 4a. Ordinary Least Squares Regressions of MFO Commercial and Public Capital Acquisition

\begin{tabular}{|c|c|c|c|c|c|c|c|c|c|c|}
\hline & \multicolumn{2}{|c|}{$(1)$} & \multicolumn{2}{|c|}{ (2) } & \multicolumn{2}{|c|}{ (3) } & \multicolumn{2}{|c|}{$(4)$} & \multicolumn{2}{|c|}{$(5)$} \\
\hline & Commercial & Public & Commercial & Public & Commercial & Public & Commercial & Public & Commercial & Public \\
\hline GDP per capita (logged) & $\begin{array}{l}-2.848 \\
(2.980)\end{array}$ & $\begin{array}{l}-0.754 \\
(4.940)\end{array}$ & $\begin{array}{l}-2.953 \\
(2.971)\end{array}$ & $\begin{array}{l}-0.164 \\
(4.938)\end{array}$ & $\begin{array}{l}-3.910 \\
(2.941)\end{array}$ & $\begin{array}{l}-0.616 \\
(4.942)\end{array}$ & $\begin{array}{l}-1.621 \\
(2.924)\end{array}$ & $\begin{array}{l}0.678 \\
(4.935)\end{array}$ & $\begin{array}{l}-2.543 \\
(2.910)\end{array}$ & $\begin{array}{l}0.289 \\
(4.945)\end{array}$ \\
\hline Net ODA ( $\%$ of GNI) & $\begin{array}{l}0.256+ \\
(0.145)\end{array}$ & $\begin{array}{l}0.400+ \\
(0.240)\end{array}$ & $\begin{array}{l}0.278+ \\
(0.145)\end{array}$ & $\begin{array}{l}0.411+ \\
(0.240)\end{array}$ & $\begin{array}{l}0.220 \\
(0.143)\end{array}$ & $\begin{array}{l}0.384 \\
(0.241)\end{array}$ & $\begin{array}{l}0.187 \\
(0.143)\end{array}$ & $\begin{array}{l}0.354 \\
(0.241)\end{array}$ & $\begin{array}{l}0.153 \\
(0.142)\end{array}$ & $\begin{array}{l}0.340 \\
(0.241)\end{array}$ \\
\hline Economic globalization & $\begin{array}{l}-0.033 \\
(0.041)\end{array}$ & $\begin{array}{l}-0.383 * * * \\
(0.068)\end{array}$ & $\begin{array}{l}-0.038 \\
(0.041)\end{array}$ & $\begin{array}{l}-0.389 * * * \\
(0.068)\end{array}$ & $\begin{array}{l}-0.046 \\
(0.041)\end{array}$ & $\begin{array}{l}-0.393 * * * \\
(0.068)\end{array}$ & $\begin{array}{l}-0.050 \\
(0.040)\end{array}$ & $\begin{array}{l}-0.397 * * * \\
(0.068)\end{array}$ & $\begin{array}{l}-0.054 \\
(0.040)\end{array}$ & $\begin{array}{l}-0.399 * * * \\
(0.068)\end{array}$ \\
\hline Country distance & $\begin{array}{l}0.025 * * * \\
(0.005)\end{array}$ & $\begin{array}{l}-0.006 \\
(0.008)\end{array}$ & $\begin{array}{l}0.024 * * * \\
(0.005)\end{array}$ & $\begin{array}{l}-0.005 \\
(0.008)\end{array}$ & $\begin{array}{l}0.023 * * * \\
(0.005)\end{array}$ & $\begin{array}{l}-0.005 \\
(0.008)\end{array}$ & $\begin{array}{l}0.023 * * * \\
(0.005)\end{array}$ & $\begin{array}{l}-0.006 \\
(0.008)\end{array}$ & $\begin{array}{l}0.022 * * * \\
(0.005)\end{array}$ & $\begin{array}{l}-0.006 \\
(0.008)\end{array}$ \\
\hline \# of active MFOs & $\begin{array}{l}0.013 \\
(0.014)\end{array}$ & $\begin{array}{l}-0.099 * * * \\
(0.023)\end{array}$ & $\begin{array}{l}0.012 \\
(0.014)\end{array}$ & $\begin{array}{l}-0.097 * * * \\
(0.023)\end{array}$ & $\begin{array}{l}0.015 \\
(0.014)\end{array}$ & $\begin{array}{l}-0.096 * * * \\
(0.023)\end{array}$ & $\begin{array}{l}0.026+ \\
(0.014)\end{array}$ & $\begin{array}{l}-0.088 * * * \\
(0.024)\end{array}$ & $\begin{array}{l}0.026+ \\
(0.014)\end{array}$ & $\begin{array}{l}-0.088 * * * \\
(0.024)\end{array}$ \\
\hline \# of new MFO founded & $\begin{array}{l}0.128 * \\
(0.051)\end{array}$ & $\begin{array}{l}-0.057 \\
(0.085)\end{array}$ & $\begin{array}{l}0.142 * * \\
(0.052)\end{array}$ & $\begin{array}{l}-0.024 \\
(0.086)\end{array}$ & $\begin{array}{l}0.107 * \\
(0.052)\end{array}$ & $\begin{array}{l}-0.040 \\
(0.087)\end{array}$ & $\begin{array}{c}0.096+ \\
(0.051)\end{array}$ & $\begin{array}{l}-0.053 \\
(0.087)\end{array}$ & $\begin{array}{l}0.075 \\
(0.051)\end{array}$ & $\begin{array}{l}-0.062 \\
(0.087)\end{array}$ \\
\hline Industry concentration & $\begin{array}{l}-4.953 * \\
(2.329)\end{array}$ & $\begin{array}{l}-5.788 \\
(3.862)\end{array}$ & $\begin{array}{l}-4.994 * \\
(2.320)\end{array}$ & $\begin{array}{l}-5.655 \\
(3.856)\end{array}$ & $\begin{array}{l}-4.715^{*} \\
(2.294)\end{array}$ & $\begin{array}{l}-5.523 \\
(3.854)\end{array}$ & $\begin{array}{l}-5.167 * \\
(2.279)\end{array}$ & $\begin{array}{l}-5.764 \\
(3.848)\end{array}$ & $\begin{array}{l}-4.925 * \\
(2.264)\end{array}$ & $\begin{array}{l}-5.662 \\
(3.848)\end{array}$ \\
\hline MFO age & $\begin{array}{l}0.053 * * * \\
(0.012)\end{array}$ & $\begin{array}{l}0.101 * * * \\
(0.020)\end{array}$ & $\begin{array}{l}0.049 * * * \\
(0.012)\end{array}$ & $\begin{array}{l}0.100 * * * \\
(0.020)\end{array}$ & $\begin{array}{l}0.047 * * * \\
(0.012)\end{array}$ & $\begin{array}{l}0.099 * * * \\
(0.020)\end{array}$ & $\begin{array}{l}0.038 * * \\
(0.012)\end{array}$ & $\begin{array}{l}0.093 * * * \\
(0.020)\end{array}$ & $\begin{array}{l}0.038 * * \\
(0.012)\end{array}$ & $\begin{array}{l}0.092 * * * \\
(0.020)\end{array}$ \\
\hline Nonprofit & $\begin{array}{l}-0.917 * * * \\
(0.239)\end{array}$ & $\begin{array}{l}-1.825 * * * \\
(0.396)\end{array}$ & $\begin{array}{l}-1.443^{* * * *} \\
(0.276)\end{array}$ & $\begin{array}{l}-1.531 * * * \\
(0.459)\end{array}$ & $\begin{array}{l}-1.404 * * * \\
(0.273)\end{array}$ & $\begin{array}{l}-1.513 * * * \\
(0.458)\end{array}$ & $\begin{array}{l}-1.371 * * * \\
(0.271)\end{array}$ & $\begin{array}{l}-1.486 * * \\
(0.458)\end{array}$ & $\begin{array}{l}-1.349 * * * \\
(0.269)\end{array}$ & $\begin{array}{l}-1.477 * * \\
(0.458)\end{array}$ \\
\hline Borrowers per loan officer & $\begin{array}{l}-0.075 \\
(0.202)\end{array}$ & $\begin{array}{l}0.549 \\
(0.335)\end{array}$ & $\begin{array}{l}-0.144 \\
(0.210)\end{array}$ & $\begin{array}{l}0.816^{*} \\
(0.349)\end{array}$ & $\begin{array}{l}-0.089 \\
(0.208)\end{array}$ & $\begin{array}{l}0.842 * \\
(0.349)\end{array}$ & $\begin{array}{l}-0.116 \\
(0.207)\end{array}$ & $\begin{array}{l}0.834 * \\
(0.349)\end{array}$ & $\begin{array}{l}-0.076 \\
(0.205)\end{array}$ & $\begin{array}{l}0.851^{*} \\
(0.349)\end{array}$ \\
\hline Transparency & $\begin{array}{l}11.190 * * * \\
(1.464)\end{array}$ & $\begin{array}{l}10.365^{* * *} \\
(2.427)\end{array}$ & $\begin{array}{l}1.971 \\
(2.791)\end{array}$ & $\begin{array}{l}14.448 * * \\
(4.639)\end{array}$ & $\begin{array}{l}1.456 \\
(2.760)\end{array}$ & $\begin{array}{l}14.204 * * \\
(4.638)\end{array}$ & $\begin{array}{l}0.757 \\
(2.747)\end{array}$ & $\begin{array}{l}13.681 * * \\
(4.636)\end{array}$ & $\begin{array}{l}0.507 \\
(2.728)\end{array}$ & $\begin{array}{l}13.575 * * \\
(4.636)\end{array}$ \\
\hline Political uncertainty & $\begin{array}{l}-0.052 \\
(0.073)\end{array}$ & $\begin{array}{l}-0.084 \\
(0.120)\end{array}$ & $\begin{array}{l}-0.038 \\
(0.072)\end{array}$ & $\begin{array}{l}-0.098 \\
(0.120)\end{array}$ & $\begin{array}{l}-0.022 \\
(0.072)\end{array}$ & $\begin{array}{l}-0.090 \\
(0.120)\end{array}$ & $\begin{array}{l}-0.040 \\
(0.071)\end{array}$ & $\begin{array}{l}-0.099 \\
(0.120)\end{array}$ & $\begin{array}{l}-0.028 \\
(0.071)\end{array}$ & $\begin{array}{l}-0.094 \\
(0.120)\end{array}$ \\
\hline Financial uncertainty & $\begin{array}{l}-0.102 * \\
(0.040)\end{array}$ & $\begin{array}{l}0.032 \\
(0.066)\end{array}$ & $\begin{array}{l}-0.093 * \\
(0.040)\end{array}$ & $\begin{array}{l}0.025 \\
(0.066)\end{array}$ & $\begin{array}{l}-0.101 * * \\
(0.039)\end{array}$ & $\begin{array}{l}0.021 \\
(0.066)\end{array}$ & $\begin{array}{l}-0.034 \\
(0.040)\end{array}$ & $\begin{array}{l}0.062 \\
(0.067)\end{array}$ & $\begin{array}{l}-0.048 \\
(0.039)\end{array}$ & $\begin{array}{l}0.056 \\
(0.067)\end{array}$ \\
\hline Size & & & $\begin{array}{l}0.851 * * * \\
(0.213)\end{array}$ & $\begin{array}{l}-0.156 \\
(0.354)\end{array}$ & $\begin{array}{l}1.149 * * * \\
(0.216)\end{array}$ & $\begin{array}{l}-0.016 \\
(0.363)\end{array}$ & $\begin{array}{l}3.481 * * * \\
(0.396)\end{array}$ & $\begin{array}{l}1.505^{*} \\
(0.668)\end{array}$ & $\begin{array}{l}3.381 * * * \\
(0.394)\end{array}$ & $\begin{array}{l}1.463^{*} \\
(0.669)\end{array}$ \\
\hline Financial performance & & & $\begin{array}{l}0.668^{*} \\
(0.392)\end{array}$ & $\begin{array}{l}-1.646^{*} \\
(0.651)\end{array}$ & $\begin{array}{l}0.628 \\
(0.387)\end{array}$ & $\begin{array}{l}-1.665^{*} \\
(0.651)\end{array}$ & $\begin{array}{l}0.446 \\
(0.386)\end{array}$ & $\begin{array}{l}-1.786^{* *} \\
(0.651)\end{array}$ & $\begin{array}{l}0.443 \\
(0.383)\end{array}$ & $\begin{array}{l}-1.787 * * \\
(0.651)\end{array}$ \\
\hline Political uncertainty X Size & & & & & $\begin{array}{l}0.313 * * * \\
(0.049)\end{array}$ & $\begin{array}{l}0.148 * \\
(0.083)\end{array}$ & & & $\begin{array}{l}0.246^{* * * *} \\
(0.050)\end{array}$ & $\begin{array}{l}0.104 \\
(0.085)\end{array}$ \\
\hline Financial uncertainty X Size & & & & & & & $\begin{array}{l}0.319 * * * \\
(0.041) \\
\end{array}$ & $\begin{array}{l}0.202 * * \\
(0.069) \\
\end{array}$ & $\begin{array}{l}0.279 * * * \\
(0.041) \\
\end{array}$ & $\begin{array}{l}0.185 * * \\
(0.070) \\
\end{array}$ \\
\hline $\mathrm{N}$ & 1746 & 1746 & 1746 & 1746 & 1746 & 1746 & 1746 & 1746 & 1746 & 1746 \\
\hline R squared & 0.388 & 0.328 & 0.394 & 0.331 & 0.408 & 0.332 & 0.416 & 0.334 & 0.424 & 0.335 \\
\hline Wald test (Degrees of freedom) & & & $7.96 * * *(2)$ & $3.46 *(2)$ & $40.03 * * *(1)$ & $3.17 *(1)$ & $61.36 * * *(1)$ & $8.60 * *(1)$ & $43.31 * * *(2)$ & $5.05 * *(2)$ \\
\hline
\end{tabular}

All models included country- and year-fixed effects.

Significance levels: $+0.10 * 0.05 * * 0.01 * * * 0.001$. One-tailed test for hypothesized variables and two-tailed test for controls. 
Table 4b. Ordinary Least Squares Regressions of MFO Commercial and Public Capital Acquisition

\begin{tabular}{|c|c|c|c|c|c|c|}
\hline & \multicolumn{2}{|c|}{$(6)$} & \multicolumn{2}{|c|}{ (7) } & \multicolumn{2}{|c|}{$(8)$} \\
\hline & Commercial & Public & Commercial & Public & Commercial & Public \\
\hline GDP per capita (logged) & $\begin{array}{l}-2.820 \\
(2.965)\end{array}$ & $\begin{array}{l}-0.109 \\
(4.939)\end{array}$ & $\begin{array}{l}-3.057 \\
(2.972)\end{array}$ & $\begin{array}{l}-0.211 \\
(4.941)\end{array}$ & $\begin{array}{l}-2.934 \\
(2.965)\end{array}$ & $\begin{array}{l}-0.160 \\
(4.942)\end{array}$ \\
\hline Net ODA ( $\%$ of GNI) & $\begin{array}{l}0.280+ \\
(0.144)\end{array}$ & $\begin{array}{l}0.412+ \\
(0.240)\end{array}$ & $\begin{array}{l}0.270+ \\
(0.145)\end{array}$ & $\begin{array}{l}0.408+ \\
(0.241)\end{array}$ & $\begin{array}{l}0.271+ \\
(0.144)\end{array}$ & $\begin{array}{l}0.409+ \\
(0.241)\end{array}$ \\
\hline Economic globalization & $\begin{array}{l}-0.034 \\
(0.041)\end{array}$ & $\begin{array}{l}-0.387 * * * \\
(0.068)\end{array}$ & $\begin{array}{l}-0.037 \\
(0.041)\end{array}$ & $\begin{array}{l}-0.389 * * * \\
(0.068)\end{array}$ & $\begin{array}{l}-0.033 \\
(0.041)\end{array}$ & $\begin{array}{l}-0.387 * * * \\
(0.068)\end{array}$ \\
\hline Country distance & $\begin{array}{l}0.024 * * * \\
(0.005)\end{array}$ & $\begin{array}{l}-0.005 \\
(0.008)\end{array}$ & $\begin{array}{l}0.024 * * * \\
(0.005)\end{array}$ & $\begin{array}{l}-0.005 \\
(0.008)\end{array}$ & $\begin{array}{l}0.024 * * * \\
(0.005)\end{array}$ & $\begin{array}{l}-0.005 \\
(0.008)\end{array}$ \\
\hline \# of active MFOs & $\begin{array}{l}0.010 \\
(0.014)\end{array}$ & $\begin{array}{l}-0.097 * * * \\
(0.023)\end{array}$ & $\begin{array}{l}0.013 \\
(0.014)\end{array}$ & $\begin{array}{l}-0.096^{* * * *} \\
(0.023)\end{array}$ & $\begin{array}{l}0.012 \\
(0.014)\end{array}$ & $\begin{array}{l}-0.097 * * * \\
(0.024)\end{array}$ \\
\hline \# of new MFO founded & $\begin{array}{l}0.170 * * \\
(0.053)\end{array}$ & $\begin{array}{l}-0.012 \\
(0.088)\end{array}$ & $\begin{array}{l}0.158 * * \\
(0.053)\end{array}$ & $\begin{array}{l}-0.016 \\
(0.089)\end{array}$ & $\begin{array}{l}0.189 * * * \\
(0.054)\end{array}$ & $\begin{array}{l}-0.004 \\
(0.090)\end{array}$ \\
\hline Industry concentration & $\begin{array}{l}-5.311 * \\
(2.318)\end{array}$ & $\begin{array}{l}-5.786 \\
(3.861)\end{array}$ & $\begin{array}{l}-4.949 * \\
(2.320)\end{array}$ & $\begin{array}{l}-5.635 \\
(3.858)\end{array}$ & $\begin{array}{l}-5.270 * \\
(2.317)\end{array}$ & $\begin{array}{l}-5.767 \\
(3.862)\end{array}$ \\
\hline MFO age & $\begin{array}{l}0.050 * * * \\
(0.012)\end{array}$ & $\begin{array}{l}0.100 * * * \\
(0.020)\end{array}$ & $\begin{array}{l}0.050 * * * \\
(0.012)\end{array}$ & $\begin{array}{l}0.100 * * * \\
(0.020)\end{array}$ & $\begin{array}{l}0.051 * * * \\
(0.012)\end{array}$ & $\begin{array}{l}0.100 * * * \\
(0.020)\end{array}$ \\
\hline Nonprofit & $\begin{array}{l}-1.432 * * * \\
(0.275)\end{array}$ & $\begin{array}{l}-1.527 * * * \\
(0.459)\end{array}$ & $\begin{array}{l}-1.460 * * * \\
(0.276)\end{array}$ & $\begin{array}{l}-1.539 * * * \\
(0.459)\end{array}$ & $\begin{array}{l}-1.451 * * * \\
(0.276)\end{array}$ & $\begin{array}{l}-1.535 * * * \\
(0.459)\end{array}$ \\
\hline Borrowers per loan officer & $\begin{array}{l}-0.124 \\
(0.210)\end{array}$ & $\begin{array}{l}0.825^{*} \\
(0.350)\end{array}$ & $\begin{array}{l}-0.133 \\
(0.210)\end{array}$ & $\begin{array}{l}0.821 * \\
(0.350)\end{array}$ & $\begin{array}{l}-0.110 \\
(0.210)\end{array}$ & $\begin{array}{l}0.831 * \\
(0.350)\end{array}$ \\
\hline Transparency & $\begin{array}{l}1.725 \\
(2.786)\end{array}$ & $\begin{array}{l}14.346^{* * *} \\
(4.642)\end{array}$ & $\begin{array}{l}1.942 \\
(2.791)\end{array}$ & $\begin{array}{l}14.435^{* *} \\
(4.641)\end{array}$ & $\begin{array}{l}1.683 \\
(2.786)\end{array}$ & $\begin{array}{l}14.327^{* *} \\
(4.644)\end{array}$ \\
\hline Political uncertainty & $\begin{array}{l}0.003 \\
(0.074)\end{array}$ & $\begin{array}{l}-0.081 \\
(0.123)\end{array}$ & $\begin{array}{l}-0.033 \\
(0.073)\end{array}$ & $\begin{array}{l}-0.095 \\
(0.121)\end{array}$ & $\begin{array}{l}0.010 \\
(0.074)\end{array}$ & $\begin{array}{l}-0.078 \\
(0.123)\end{array}$ \\
\hline Financial uncertainty & $\begin{array}{l}-0.086^{*} \\
(0.039)\end{array}$ & $\begin{array}{l}0.027 \\
(0.066)\end{array}$ & $\begin{array}{l}-0.095 * \\
(0.040)\end{array}$ & $\begin{array}{l}0.024 \\
(0.066)\end{array}$ & $\begin{array}{l}-0.089 * \\
(0.040)\end{array}$ & $\begin{array}{l}0.026 \\
(0.066)\end{array}$ \\
\hline Size & $\begin{array}{l}0.880^{* * * *} \\
(0.213)\end{array}$ & $\begin{array}{l}-0.145 \\
(0.355)\end{array}$ & $\begin{array}{l}0.857 * * * \\
(0.213)\end{array}$ & $\begin{array}{l}-0.154 \\
(0.355)\end{array}$ & $\begin{array}{l}0.887 * * * \\
(0.213)\end{array}$ & $\begin{array}{l}-0.141 \\
(0.355)\end{array}$ \\
\hline Financial performance & $\begin{array}{l}0.572 \\
(0.392)\end{array}$ & $\begin{array}{l}-1.686^{* *} \\
(0.654)\end{array}$ & $\begin{array}{l}0.561 \\
(0.400)\end{array}$ & $\begin{array}{l}-1.694 * \\
(0.666)\end{array}$ & $\begin{array}{l}0.446 \\
(0.401)\end{array}$ & $\begin{array}{l}-1.742 * * \\
(0.669)\end{array}$ \\
\hline Political uncertainty X Financial performance & $\begin{array}{l}-0.175^{* *} \\
(0.060)\end{array}$ & $\begin{array}{l}-0.072 \\
(0.100)\end{array}$ & & & $\begin{array}{l}-0.180 * * \\
(0.060)\end{array}$ & $\begin{array}{l}-0.075 \\
(0.101)\end{array}$ \\
\hline Financial uncertainty X Financial performance & & & $\begin{array}{l}0.054 \\
(0.042) \\
\end{array}$ & $\begin{array}{l}0.024 \\
(0.069) \\
\end{array}$ & $\begin{array}{l}0.062 \\
(0.042) \\
\end{array}$ & $\begin{array}{l}0.028 \\
(0.070) \\
\end{array}$ \\
\hline $\begin{array}{l}\mathrm{N} \\
\mathrm{R} \text { squared } \\
\text { Wald test (Degrees of freedom) }\end{array}$ & $\begin{array}{l}1746 \\
0.397 \\
8.39 * *(1) \\
\end{array}$ & $\begin{array}{l}1746 \\
0.331 \\
0.52(1)\end{array}$ & $\begin{array}{l}1746 \\
0.395 \\
1.67(1)\end{array}$ & $\begin{array}{l}1746 \\
0.331 \\
0.12(1)\end{array}$ & $\begin{array}{l}1746 \\
0.398 \\
5.30 * *(2) \\
\end{array}$ & $\begin{array}{l}1746 \\
0.331 \\
0.34(2)\end{array}$ \\
\hline
\end{tabular}

All models included country- and year-fixed effects.

Significance levels: $+0.10 * 0.05 * * 0.01 * * * 0.001$. One-tailed test for hypothesized variables and two-tailed test for controls. 
Table 5. The Relationship between MFO Size and Social Outreach

\begin{tabular}{lcc}
\cline { 2 - 3 } & $\begin{array}{c}\text { Average } \\
\text { loan size }\end{array}$ & $\begin{array}{c}\text { Proportion of } \\
\text { women } \\
\text { borrowers }\end{array}$ \\
\hline Size & $0.100 * * *$ & $-0.004+$ \\
& $(0.012)$ & $(0.003)$ \\
\hline $\mathrm{N}$ & 10893 & 9319 \\
Log likelihood & -6449.854 & 9052.774 \\
\hline
\end{tabular}

Standard errors in parentheses.

Significance levels: $+0.10 * 0.05 * * 0.01 * * * 0.001$ 
Figure 1. Plots of Significant Interactions between Political/Financial Uncertainty and MFO Size
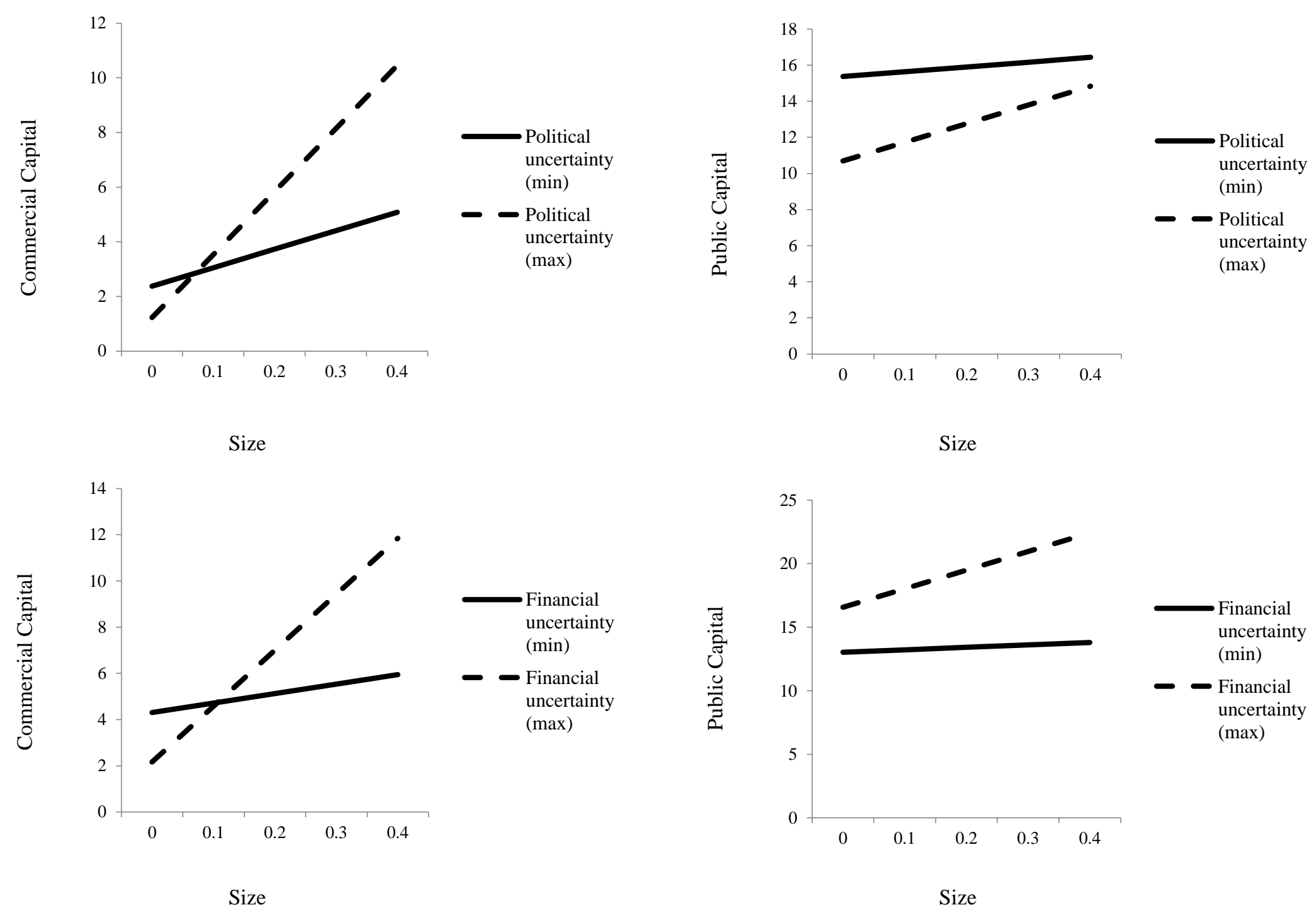
Figure 2. Plot of Significant Interaction between Political Uncertainty and Financial Performance

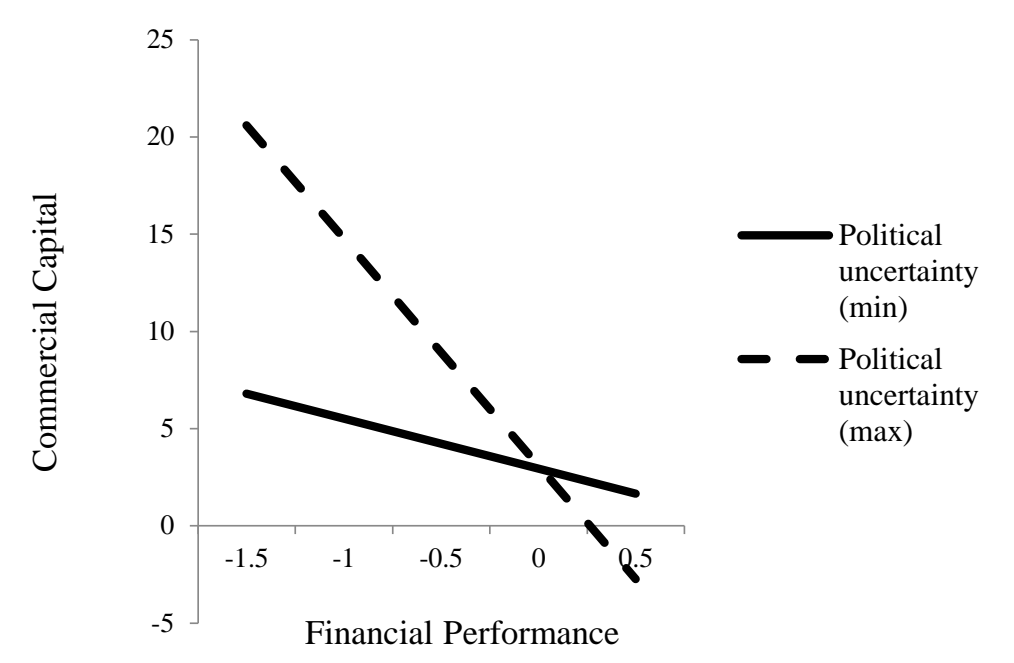




\section{REFERENCES}

Abrams, J., \& Von Stauffenberg, D. 2007. Are public development institutions crowding out private investment in microfinance. MF Insights.

Adger, W. N. 2006. Vulnerability. Global environmental change, 16(3): 268-281.

Aiken, L. S., \& West, S. G. 1991. Multiple Regression: Testing and Interpreting Interactions Thousand Oaks, CA: Sage Publications.

Alesina, A., \& Dollar, D. 2000. Who gives foreign aid to whom and why? Journal of economic growth, 5(1): 33-63.

Allayannis, G., \& Weston, J. P. 2001. The use of foreign currency derivatives and firm market value. Review of Financial Studies, 14(1): 243-276.

Almandoz Rios, J. 2014. Founding teams as carriers of competing logics: When institutional forces preduct banks' risk exposure. Administrative Science Quarterly, 59(3): 442-473.

Angelucci, M., Karlan, D., \& Zinman, J. 2012. Win some lose some? Evidence from a randomized microcredit program placement experiment by Compartamos Banco. NBER Working Paper.

Arellano, C. 2008. Default risk and income fluctuations in emerging economies. American Economic Review, 98(3): 690-712.

Armendariz, B., \& Morduch, J. 2010. The Economics of Microfinance (2nd ed.). Cambridge, MA: MIT Press.

Audia, P. G., Locke, E. A., \& Smith, K. G. 2000. The paradox of success: An archival and a laboratory study of strategic persistence following radical environmental change. Academy of Management Journal, 43(5): 837-853.

Ault, J. K., \& Spicer, A. 2014. The institutional context of poverty: State fragility as a predictor of cross-national variation in commercial microfinance lending. Strategic Management Journal, 35(12): 1818-1838.

Banerjee, A., Duflo, E., Glennerster, R., \& Kinnan, C. 2015. The miracle of microfinance? Evidence from a randomized evaluation. American Economic Journal: Applied Economics, 7(1): 22-53.

Battilana, J., \& Dorado, S. 2010. Building Sustainable Hybrid Organizations: The Case of Commercial Microfinance Organizations. Academy of Management Journal, 53(6): 1419-1440.

Battilana, J., \& Lee, M. 2014. Advancing research on hybrid organizing - Insights from the study of social enterprises. Academy of Management Annals, 8(1): 397-441.

Battilana, J., Sengul, M., Pache, A.-c., \& Model, J. 2014. Harnessing productive tensions in hybrid organizations: The case of work integration social enterprises. Academy of Management Journal, 34: 81-100.

Beckman, C. M., Haunschild, P. R., \& Phillips, D. J. 2004. Friends or strangers? Firm-specific uncertainty, market uncertainty, and network partner selection. Organization science, 15(3): 259-275.

Bekaert, G., Harvey, C. R., Lundblad, C. T., \& Siegel, S. 2014. Political risk spreads. Journal of International Business Studies, 45(4): 471-493.

Berk, J. B. 1995. A critique of size-related anomalies. Review of Financial Studies, 8(2): 275286.

BlueOrchard. 2015. Expertise. accessed from, http://www.blueorchard.com/about-us/what-we$\underline{d o /}$. 
Boeker, W. 1997. Strategic change: The influence of managerial characteristics and organizational growth. Academy of Management Journal, 40(1): 152-170.

Boubakri, N., Mansi, S. A., \& Saffar, W. 2013. Political institutions, connectedness, and corporate risk-taking. Journal of International Business Studies, 44(3): 195-215.

Boxenbaum, E., \& Battilana, J. 2005. Importation as innovation: Transposing managerial practices across fields. Strategic Organization, 3(4): 355-383.

Child, J. 1972. Organization structure and strategies of control: A replication of the Aston study. Administrative Science Quarterly, 17: 163-177.

Clemens, E. S., \& Cook, J. M. 1999. Politics and institutionalism: Explaining durability and change. Annual Review of Sociology, 25: 441-466.

Click, R. W. 2005. Financial and political risks in US direct foreign investment. Journal of International Business Studies, 36(5): 559-575.

Cobb, J. A. 2016. How firms shape income inequality: Stakeholder power, executive decisionmaking, and the structuring of employment relationships. Academy of Management Review, 41(2): 324-348.

Cull, R., Demirguc-Kunt, A., \& Morduch, J. 2009. Microfinance Meets the Market. Journal of Economic Perspectives, 23(1): 167-192.

Davis, J. P., Eisenhardt, K. M., \& Bingham, C. B. 2009. Optimal structure, market dynamism, and the strategy of simple rules. Administrative Science Quarterly, 54(3): 413-452.

Dell'Ariccia, G., \& Marquez, R. 2010. Risk and the Corporate Structure of Banks. Journal of Finance, 65(3): 1075-1096.

Delmestri, G., \& Greenwood, R. 2016. How Cinderella Became a Queen Theorizing Radical Status Change. Administrative Science Quarterly: 0001839216644253.

Dobrev, S. D., Kim, T.-Y., \& Carroll, G. R. 2003. Shifting gears, shifting niches: Organizational inertia and change in the evolution of the US automobile industry, 1885-1981. Organization Science, 14(3): 264-282.

Dreher, A. 2006. Does globalization affect growth? Evidence from a new index of globalization. Applied Economics, 38(10): 1091-1110.

Emery, F. E., \& Trist, E. L. 1965. The causal texture of organizational environments. Human relations, 18(1): 21-32.

Erb, C. B., Campbell, H. R., \& Viskanta, T. E. 1996. Political risk, economic risk, and financial risk. Financial Analysts Journal(November/December): 29-46.

Fama, E. F., \& French, K. R. 2012. Size, value, and momentum in international stock returns. Journal of financial economics, 105(3): 457-472.

Feldman, M. S., \& Pentland, B. T. 2003. Reconceptualizing organizational routines as a source of flexibility and change. Administrative Science Quarterly, 48: 94-118.

Fleck, R. K., \& Kilby, C. 2006. How do political changes influence US bilateral aid allocations? Evidence from panel data. Review of Development Economics, 10(2): 210-223.

Frank, C. 2008. Stemming the tide of mission drift: Microfinance transformation and the double bottom line: Women's World Banking Focus Note.

Garmaise, M. J., \& Natividad, G. 2010. Information, the Cost of Credit, and Operational Efficiency: An Empirical Study of Microfinance. Review of Financial Studies, 23(6): 2560-2590.

Garmaise, M. J., \& Natividad, G. 2013. Cheap credit, lending operations, and international politics: The case of global microfinance. Journal of Finance, 68(4): 1551-1576. 
Geczy, C., Minton, B. A., \& Schrand, C. 1997. Why firms use currency derivatives. Journal of Finance, 52(4): 1323-1354.

George, G. 2005. Slack resources and the performance of privately held firms. Academy of Management Journal, 48(4): 661-676.

George, G., Kotha, R., Parikh, P., Alnuaimi, T., \& Bahaj, A. 2015. Social structure, reasonable gain, and entrepreneurship in Africa. Strategic Management Journal, Forthcoming.

Geringer, J. M. 1991. Strategic determinants of partner selection criteria in international joint ventures. Journal of international business studies: 41-62.

Geroski, P. A., Mata, J., \& Portugal, P. 2010. Founding conditions and the survival of new firms. Strategic Management Journal, 31(5): 510-529.

Glisovic, J., \& Moretto, L. 2012. How Have Market Challenges Affected Microfinance Investment Funds?

Glisovic, J., \& Reille, X. 2010. Microfinance investors adjust strategy in tougher market conditions.

Gonzalez, A. 2010. Microfinance funders profiles: A short guide for young and small institutions still looking for a match. MIX Data Brief, 6.

Goodman, P. 2007. Microfinance investment funds: Objectives, players, potential, Microfinance investment funds: 11-45: Springer.

Greenwood, R., Raynard, M., Kodeih, F., Micelotta, E., \& Lounsbury, M. 2011. Institutional complexity and organizational responses. Academy of Management Annals, 5(1): 317371.

Greenwood, R., \& Suddaby, R. 2006. Institutional entrepreneurship in mature fields: The big five accounting firms. Academy of Management Journal, 49(1): 27-48.

Griffith, R., \& Evans, M. 2012. Development Finance Institutions: Advocates for International Development, Reed Smith LLP.

Haunschild, P. R., \& Miner, A. S. 1997. Modes of interorganizational imitation: The effects of outcome salience and uncertainty. Administrative Science Quarterly, 42(3): 472-500.

Haveman, H. A. 1993. Follow the Leader: Mimetic Isomorphism and Entry into New Markets. Administrative Science Quarterly, 38(4): 593-627.

Haveman, H. A., \& Rao, H. 1997. Structuring a theory of moral sentiments: Institutional and organizational coevolution in the early thrift industry. American Journal of Sociology, 102(6): 1606-1651.

Henisz, W. J. 2000. The institutional environment for multinational investment. Journal of Law, Economics, and Organization, 16(2): 334-364.

Henisz, W. J., \& Delios, A. 2004. Information or influence? The benefits of experience for managing political uncertainty. Strategic Organization, 2(4): 389-421.

Hitt, M. A., Dacin, M. T., Levitas, E., Arregle, J.-L., \& Borza, A. 2000. Partner selection in emerging and developed market contexts: Resource-based and organizational learning perspectives. Academy of Management Journal, 43(3): 449-467.

Hoffman, S. L. 1998. The law and business of international project finance--a resource for governments, sponsors, lenders, lawyers and project particapants. Hague K luwer Law international: $24-29$.

Howell, L. D. 2001. The Handbook of Country and Political Risk Analysis. East Syracuse, NY: The PRS Group. 
Josefy, M., Kuban, S., Ireland, R., \& Hitt, M. 2015. All Things Great and Small: Organizational Size, Boundaries of the Firm, and a Changing Environment. The Academy of Management Annals(forthcoming): 1-112.

Karlan, D., \& Zinman, J. 2010. Expanding credit access: Using randomized supply decisions to estimate the impacts. Review of Financial Studies, 23(1): 433-464.

Katila, R., Rosenberger, J. D., \& Eisenhardt, K. M. 2008. Swimming with sharks: Technology ventures, defense mechanisms and corporate relationships. Administrative Science Quarterly, 53(2): 295-332.

Kennedy, M. T., \& Fiss, P. C. 2009. Institutionalization, Framing, and Diffusion: The Logic of Tqm Adoption and Implementation Decisions among Us Hospitals. Academy of Management Journal, 52(5): 897-918.

Kennedy, P. 1992. A guide to econometrics. Oxford: Blackwell.

Kiva. 2015. Kiva's Role. Accessed from, http://www.kiva.org/about/risk/kiva-role.

Lacalle, M., \& Alfonso, J. 2011. Foreign aid versus microfinance, SASE Annual Conference. Madrid, Spain.

Lafourcade, A., Isern, J., Mwangi, P., \& Brown, M. 2006. Overview of the outreach and financial performance of microfinance institutions in Africa. MicroBanking Bulletin(April): 3-14.

Lahaye, E., Rizvanolli, R., \& Dashi, E. 2012. Current trends in cross-border funding for microfinance. Washington, DC: World Bank.

Lancaster, C. 2008. Foreign aid: Diplomacy, development, domestic politics: University of Chicago Press.

Ledgerwood, J., Earne, J., \& Nelson, C. 2013. The new microfinance handbook: A financial market system perspective: World Bank Publications.

Li, Q. 2009. Democracy, Autocracy, and Expropriation of Foreign Direct Investment. Comparative Political Studies, 42(8): 1098-1127.

Li, S. X., \& Rowley, T. J. 2002. Inertia and evaluation mechanisms in interorganizational partner selection: Syndicate formation among US investment banks. Academy of Management Journal, 45(6): 1104-1119.

Lounsbury, M. 2007. A tale of two cities: Competing logics and practice variation in the professionalizing of mutual funds. Academy of Management Journal, 50(2): 289-307.

Lounsbury, M., \& Crumley, E. T. 2007. New practice creation: An institutional perspective on innovation. Organization Studies, 28(7): 993-1012.

Luminis. 2012. The state of microfinance investment 2012: 1-18: MicroRate.

Lützenkirchen, C., Weistroffer, C., \& Speyer, B. 2012. Microfinance in evolution: An industry between crisis and advancement. Deutsche Bank Research 13.

Mair, J., Marti, I., \& Ventresca, M. 2012. Building inclusive markets in rural Bangladesh: How intermediaries work institutional voids. Academy of Management Journal, 55(4): 819850.

Marquis, C., \& Lounsbury, M. 2007. Vive la resistance: Competing logics and the consolidation of US community banking. Academy of Management Journal, 50(4): 799-820.

Marquis, C., \& Raynard, M. 2015. Institutional strategies in emerging markets. Academy of Management Annals, 9(1): 291-335.

Mersland, R., \& Strom, R. O. 2010. Microfinance mission drift? World Development, 38(1): 2836. 
MicroRate. 2013. Microfinance Institution Tier Definitions. accessed from, http://www.microrate.com/media/downloads/2013/04/MicroRate-White-paperMicrofinance-Institution-Tier-Definitions.pdf.

Morduch, J. 2000. The microfinance schism. World Development, 28(4): 617-629.

North, D. C. 1991. Institutions. Journal of Economic Perspectives, 5(1): 97-112.

Otero, M. 1999. Bringing development back into microfinance. Journal of Microfinance/ESR Review, 1(1): 8-19.

Otero, M., \& Rhyne, E. 1994. The new world of microenterprise finance: building healthy financial institutions for the poor: Intermediate Technology Publications Ltd (ITP).

Pache, A.-C., \& Santos, F. 2013. Inside the hybrid organization: Selective coupling as a response to competing institutional logics. Academy of Management Journal, 56(4): 972-1001.

Pahnke, E. C., Katila, R., \& Eisenhardt, K. M. 2015. Who takes you to the dance? How partners' institutional logics influence innovation in young firms. Administrative Science Quarterly, 60(4): 596-633.

Petersen, M. A., \& Rajan, R. G. 1994. The benefits of lending relationships: Evidence from small business data. The Journal of Finance, 49(1): 3-37.

Pfeffer, J., \& Salancik, G. R. 1978. The external control of organizations: a resource dependence perspective. New York: Harper \& Row.

Podolny, J. M. 1994. Market Uncertainty and the Social Character of Economic Exchange. Administrative Science Quarterly, 39(3): 458-483.

Prahalad, C. K., \& Bettis, R. A. 1986. The dominant logic: A new linkage between diversity and performance. Strategic Management Journal, 7: 485-501.

Ramady, M. A. 2014. Political, Economic, and Financial Country Risk: Analysis of the Gulf Cooperation Council. Heidelberg, Switzerland: Springer International.

Rao, H., Monin, P., \& Durand, R. 2003. Institutional change in Toque Ville: Nouvelle cuisine as an identity movement in French gastronomy. American Journal of Sociology, 108(4): 795-843.

Reay, T., Goodrick, E., Waldorff, S., \& Casebeer, A. 2016. Getting Leopards to Change their Spots: Co-Creating a New Professional Role Identity. Academy of Management Journal: amj. 2014.0802.

Reille, X., \& Forster, S. 2008. Foreign capital investment in microfinance: balancing social and financial returns.

Reille, X., Forster, S., \& Rozas, D. 2011. Foreign capital investment in microfinance: Reassessing financial and social returns. Focus Note, 71.

Roberts, P. W. 2013. The profit orientation of microfinance institutions and effective interest rates. World Development, 41: 120-131.

Sapundzhieva, R. 2011. Funding microfinance - a focus on debt financing. Microfinance Bulletin, November: 1-8.

Scott, W. R. 2001. Institutions and organizations (2nd ed.). Thousand Oaks, Calif.: Sage Publications.

Sen, A. 1981. Poverty and famines: an essay on entitlement and deprivation: Oxford university press.

Smets, M., Morris, T., \& Greenwood, R. 2012. From practice to field: A multilevel model of practice-driven institutional change. Academy of Management Journal, 55(4): 877-904.

Soussanov, D. 2002. Statistical Data Choice in Country Risk Analysis. Journal of Investing, 11(4): 39-42. 
Tchuigoua, H. T. 2014. Institutional framework and capital structure of microfinance institutions. Journal of Business Research, 67(10): 2185-2197.

Thompson, J. D. 1967. Organizations in action: social science bases of administrative theory. New York: McGraw-Hill.

Thornton, P. H. 1999. The sociology of entrepreneurship. Annual Review of Sociology, 25: 1946.

Thornton, P. H., \& Ocasio, W. 1999. Institutional logics and the historical contingency of power in organizations: Executive succession in the higher education publishing industry, 19581990. American Journal of Sociology, 105(3): 801-843.

Thornton, P. H., Ocasio, W., \& Lounsbury, M. 2012. The institutional logics perspective: A new approach to culture, structure and process. Oxford, UK: Oxford University Press.

Tilcsik, A., \& Marquis, C. 2013. Punctuated Generosity: How Mega-events and Natural Disasters Affect Corporate Philanthropy in US Communities. Administrative Science Quarterly, 58(1): 111-148.

Vasudeva, G., Zaheer, A., \& Hernandez, E. 2013. The embeddedness of networks: Institutions, structural holes, and innovativeness in the fuel cell industry. Organization Science, 24(3): 645-663.

Von Stauffenberg, D., \& Rosas, D. 2011. Role Reversal Revisited. Are Public Development Institutions Still Crowding-out Private Investment in Microfinance? Washington DC: MicroRate.

Wiesner, S., \& Quien, D. 2010. Can "Bad" Microfinance Practices Be the Consequence of Too Much Funding Chasing Too Few Microfinance Institutions?: ADA Discussion Paper.

Wooldridge, J. M. 2006. Introductory Econometric Analysis. Mason, OH: Thomson.

Wry, T., Cobb, A. J., \& Aldrich, H. E. 2013. More than a metaphor: Assessing the historical legacy of resource dependence and its contemporary promise as a theory of environmental complexity. Academy of Management Annals, 7(1): 439-486.

Wry, T., Lounsbury, M., \& Glynn, M. A. 2011. Legitimating Nascent Collective Identities: Coordinating Cultural Entrepreneurship. Organization Science, 22(2): 449-463.

Wry, T., Lounsbury, M., \& Jennings, P. D. 2014. Hybrid vigor: Securing venture capital by spanning categories in nanotechnology. Academy of Management Journal, 57(5): 13091333.

Wry, T., \& York, J. 2015. An Identity Based Approach to Social Enterprise. Academy of Management Review: amr. 2013.0506.

York, J., Hargrave, T., \& Pacheco, D. 2015. Converging winds: Logic hybridization in the Colorado wind energy field. Academy of Management Journal: amj. 2013.0657.

Yunus, M. 1999. Banker to the poor: Micro-lending and the battle against world poverty (1st ed.). New York: PublicAffairs.

Zellner, A., \& Huang, D. S. 1962. Further properties of efficient estimators for seemingly unrelated regression equations. International Economic Review, 3: 300-313.

Zhao, E. Y., Fisher, G., Lounsbury, M., \& Miller, D. 2016. Optimal distinctiveness revisited: Broadening the interface between institutional theory and strategic management. Strategic Management Journal, Forthcoming. 
J. Adam Cobb (adamcobb@wharton.upenn.edu) is an Assistant Professor of Management at the Wharton School, University of Pennsylvania. He received his $\mathrm{PhD}$ in Management from the University of Michigan, Ross School of Business. His research examines the historical development and reconfiguration of employment relations and their implications.

Tyler Wry (twry@wharton.upenn.edu) is an Assistant Professor of Management at the Wharton School, University of Pennsylvania. His research examines the formation and functioning of hybrid ventures, with a particular focus on understanding when and why these organizations are supported by external resource providers. Tyler's work has appeared in outlets such as the Academy of Management Annals, the Academy of Management Journal, the Academy of Management Review, the Journal of Business Venturing, and Organization Science.

Eric Yanfei Zhao (ericzhao@indiana.edu) is an Assistant Professor of Management and Entrepreneurship at the Kelley School of Business, Indiana University. He received his $\mathrm{PhD}$ from the University of Alberta. His current research interests are strategy and organization theory, institutional theory, and social entrepreneurship. 